\title{
Long term evolution of heat budget in the Mediterranean Sea from Med-CORDEX forced and coupled simulations
}

\author{
Ali Harzallah ${ }^{1}$ - Gabriel Jordà ${ }^{2}$ Clotilde Dubois ${ }^{3}$. Gianmaria Sannino ${ }^{4}$. \\ Adriana Carillo ${ }^{4}$ Laurent $_{\mathrm{Li}^{5}} \cdot$ Thomas Arsouze $^{6} \cdot$ Leone Cavicchia $^{7}$. \\ Jonathan Beuvier $^{8} \cdot$ Naveed Akhtar ${ }^{9}$
}

Received: 25 December 2015 / Accepted: 15 September 2016 / Published online: 1 October 2016

(c) The Author(s) 2016. This article is published with open access at Springerlink.com

\begin{abstract}
This study evaluates the Mediterranean Sea heat budget components from a set of forced and coupled simulations performed in the frame of the Med-CORDEX project. The simulations use regional climate system models (RCSMs) dedicated to the Mediterranean area and driven by the ERA40/ERA-Interim reanalyses. The study focuses on the period 1980-2010. Interannual variations of the average net heat flux at the sea surface are consistent among models but the spread in the mean values is large (from -4.8 to $+2.2 \mathrm{Wm}^{-2}$ ) with the coupled models showing the lowest heat loss from the sea. For the heat flux at the Strait of Gibraltar both interannual variations and mean values show a large intermodel spread. The basin average temperature shows positive trends with highest values in the coupled models; it also shows interannual variations that are in good agreement with observations. The heat content rate is calculated based on the derivative of the average
\end{abstract}

This paper is a contribution to the special issue on MedCORDEX, an international coordinated initiative dedicated to the multi-component regional climate modelling (atmosphere, ocean, land surface, river) of the Mediterranean under the umbrella of HyMeX, CORDEX, and Med-CLIVAR and coordinated by Samuel Somot, Paolo Ruti, Erika Coppola, Gianmaria Sannino, Bodo Ahrens, and Gabriel Jordà.

Ali Harzallah

ali.harzallah@instm.rnrt.tn

1 National Institute of Marine Science and Technologies, 28, rue du 2 mars 1934, 2025 Salammbô, Tunisia

2 Institut Mediterrani d'Estudis Avançats, Esporles, Mallorca, Spain

3 Météo France - Centre National de Recherches Météorologiques, Toulouse, France

4 Energy and Environment Modeling Technical Unit, ENEA, Rome, Italy temperature and is found to be significantly correlated for most models with the net heat flux at the sea surface (average correlation $\sim 0.5$ ) but not with the net heat flux through the Strait of Gibraltar (average correlation $\sim 0.2$ ), suggesting that in the considered RCSMs the interannual variability of the heat content rate is mainly driven by the surface heat fluxes. The resemblance between the simulated and observed heat content rates is stronger in the forced models than in the coupled ones. This is explained by the stronger constraint applied to the forced models by the use of the surface temperature relaxation to observations. The temperature of the outflowing water through the Strait of Gibraltar shows positive and significant trends, also higher in the coupled models. It is suggested that the Mediterranean Sea warming found in most models and in particular in the coupled ones, induces a change of the hydrographic conditions that affects the Strait of Gibraltar.

Keywords Mediterranean Sea $\cdot$ Heat budget $\cdot$ Heat content · Strait of Gibraltar · Regional climate models

5 Laboratoire de Météorologie Dynamique, CNRS, Sorbonne Universités, UPMC Univ Paris 06, Jussieu, Paris, France

6 Unité de Mécanique, ENSTA-Paris Tech, Palaiseau, France

7 Centro Euro-Mediterraneo sui Cambiamenti Climatici, Lecce, Italy

8 Mercator Océan, Ramonville Saint-Agne, France

9 Institut fuer Atmosphaere und Umwelt, Goethe Universitaet Frankfurt, Frankfurt/Main, Germany 


\section{Introduction}

The Mediterranean Sea is a semi-enclosed basin connected to the Atlantic Ocean at the Strait of Gibraltar. It is also connected to the Red Sea at the Suez channel and to the Black Sea at the Strait of Bosphorus. There is increasing evidence that hydrographic conditions in several areas of the Mediterranean basin are changing. The western basin deep waters, among the most observed and studied water masses of the Mediterranean Sea, show increase in temperature $\left(\sim+3.5 \times 10^{-3}{ }^{\circ} \mathrm{C}\right.$ year $^{-1}$, Bethoux et al. 1998; Bethoux and Gentili 1999). Corresponding changes in the eastern Mediterranean are less evident albeit Manca et al. (2004) showed a temperature increase in the Ionian $\left(\sim+2.8 \times 10^{-3}{ }^{\circ} \mathrm{C}\right.$ year $\left.^{-1}\right)$ and Levantine basins $\left(\sim+3.7 \times 10^{-3}{ }^{\circ} \mathrm{C}\right.$ year $\left.^{-1}\right)$. In the latter basin a lower increase $\left(\sim+1.2 \times 10^{-3}{ }^{\circ} \mathrm{C}_{\text {year }}{ }^{-1}\right)$ was found by Tsimplis and Baker (2000). Changes in the Mediterranean water characteristics are shown to impact the water leaving the Mediterranean Sea through the Strait of Gibraltar. Millot et al. (2006) indeed found a large warming of the densest Mediterranean water outflowing through the Strait of Gibraltar $\left(\sim+0.3{ }^{\circ} \mathrm{C}\right.$ in early 2000 s compared to 20 years earlier). An increase in the Mediterranean Sea temperature during the last decades was also shown by CriadoAldeanueva et al. (2012). The increase is deduced from an unbalance between the net heat flux at the Strait of Gibraltar (based on a combination of climatological data sets and in situ measurements), and a long-term average of the net heat flux at the sea surface. Despite the above mentioned evidences of changes in the thermal properties of the Mediterranean basin, a full understanding of the mechanisms that produce them and of the contribution of the heat budget components to these changes is still not reached.

The Mediterranean heat budget equation can be written as follows:

$\frac{\Delta H C}{\Delta t}=S H F+G H F+B H F+S C H F+R H F$

where $\mathrm{HC}$ is the heat content (the thermal energy stored in the basin) and $\frac{\Delta H C}{\Delta t}$ is the heat content rate. $\frac{\Delta H C}{\Delta t}$ results from an unbalance between the different heat fluxes at the basin boundaries: the net heat flux at the sea surface (SHF), at the Strait of Gibraltar (GHF), at the Bosphorus Strait (BHF), in the Suez channel (SCHF) and the heat input by the rivers (RHF). The contribution of the rivers, the Bosphorus Strait and the Suez channel are much less important in terms of the water flux exchange, and thus in the heat exchange (e.g. Bethoux 1979; Harzallah et al. 1993; Garrett et al. 1993; Mariotti et al. 2002). Hence, the heat content rate in the Mediterranean Sea is mainly controlled by the net heat fluxes at the Strait of Gibraltar (GHF) and at the sea surface (SHF).
Several estimates of the heat budget components GHF and SHF were obtained based on observations and model simulation (e.g. Garrett et al. 1993; Astraldi et al. 1999; Pettenuzzo et al. 2010; Criado-Aldeanueva et al. 2012; Sevault et al. 2014). The net heat flux through the Strait of Gibraltar (GHF) depends on the water exchanged at this strait. The flow at this strait has two branches: an inflow of Atlantic waters into the Mediterranean operating in the upper layers and an outflow towards the opposite direction operating in the lower layers. The observation estimates for the mean inward and outward fluxes are respectively +0.72 and $-0.68 \mathrm{~Sv}$ (Bryden et al. 1994), +0.81 and $-0.76 \mathrm{~Sv}$ (Baschek et al. 2001) and +0.78 and $-0.67 \mathrm{~Sv}$ (Tsimplis and Bryden 2000). For the period 1994-1996 Astraldi et al. (1999) found higher values +1.01 and $-0.97 \mathrm{~Sv}$. More recently, Soto-Navarro et al. (2010) obtained $+0.81 \pm 0.06 \mathrm{~Sv}$ and $-0.78 \pm 0.05 \mathrm{~Sv}$ based on direct current meter observations during the period 2004-2009 and a combination of different products for the surface freshwater flux in the Mediterranean. In the frame of the European project CIRCE five RCSMs were used to simulate the climate evolution of the Mediterranean region during the period 1950-2050 (Gualdi et al. 2013a, b; Dubois et al. 2012). The ensemble average of the mean inward and outward fluxes for the 1961-1990 period were +0.85 and $-0.81 \mathrm{~Sv}$, respectively. Hence the amount of water being exchanged at the Strait has been quantified to be of the order of $0.8-1 \mathrm{~Sv}$ in both layers. The net water flux corresponding to the above mentioned estimates ranges between +0.04 and $+0.11 \mathrm{~Sv}$.

Returning to the heat flux through the Strait of Gibraltar, comparatively fewer estimates are available. Based on current meter measurements at the strait, Garrett et al. (1993) and Macdonald et al. (1994) respectively obtained $+7 \pm 3 \mathrm{Wm}^{-2}$ and $+5.2 \pm 1.3 \mathrm{Wm}^{-2}$ as net heat flux. Combining climatological values with in situ measurements Criado-Aldeanueva et al. (2012) proposed $+3.2 \pm 1.5 \mathrm{Wm}^{-2}$. Astraldi et al. (1999) estimated the net, inward and outward heat fluxes from measurements for the period 1994-1996 as corresponding to $+5.0,+32.3$ and $-27.2 \mathrm{Wm}^{-2}$, respectively. From the CIRCE simulations the ensemble average mean values of these fluxes are found $+4.31,+19.59$ and $-15.27 \mathrm{Wm}^{-2}$ for the period 19611990. However the CIRCE simulations showed large intermodel spread and, as stated by Gualdi et al. (2013b), their heat flux estimates should be carefully considered.

An accurate estimate of the net heat flux at the sea surface (SHF) is still not reached due to the lack of observations over the sea to constrain the atmospheric products. Thus, the closure of the heat budget remained a concern in several studies (e.g. Harzallah 1990; Garrett et al. 1993; Josey et al. 1999). Sevault et al. (2014) compared different estimates of the surface heat flux components for the period 
1985-2004 based on in situ and satellite observations and found net heat flux values ranging from -10 to $0 \mathrm{Wm}^{-2}$. The well known ERA40 (Uppala et al. 2005) and ERAInterim reanalyses (Dee et al. 2011) provided surface and atmospheric fields widely used in several modelling studies of the Mediterranean Sea. However these analyses present some non negligible biases. The ERA40 net heat flux at the sea surface is shown to be too large $\left(-13 \mathrm{Wm}^{-2}\right.$ for the period 1958-2001, Pettenuzzo et al. 2010; $-15 \pm 6 \mathrm{Wm}^{-2}$ for the period 1961-2000, Sanchez-Gomez et al. 2011). Pettenuzzo et al. (2010) showed that such a too large heat flux is basically the result of underestimation of the shortwave radiation. They also showed that despite being few, severe winter episodes induce important heat losses, thus largely contributing to the total heat flux biases. The authors used satellite and in situ observational data sets to obtain a corrected net heat flux of $-7 \mathrm{Wm}^{-2}$. The European project ENSEMBLES generated an ensemble of regional dynamical downscaling sets of ERA40. In particular, twelve highresolution $(25 \mathrm{~km})$ atmospheric RCSMs were forced by the same ERA40 forcing for the period 1961-2000. SanchezGomez et al. (2011) compared the simulated net heat fluxes at the sea surface and obtained an ensemble average value of $-9 \mathrm{Wm}^{-2}$ but the spread was large (from -40 to $+21 \mathrm{Wm}^{-2}$ ). They also showed large differences in the net heat flux values obtained from a combination of different data sets $\left(-3,+5\right.$ and $\left.+9 \mathrm{Wm}^{-2}\right)$. The CIRCE simulations provided net heat flux values corresponding to a heat loss by the sea and satisfying the heat budget closure ( -6 to $-2 \mathrm{Wm}^{-2}$ for the period 1961-1990; Gualdi et al. 2013b; Dubois et al. 2012). The last authors concluded that oceanatmosphere coupling is a necessary approach for consistent climate simulations of the Mediterranean Sea.

Recently a new ensemble of simulations has been set up in order to simulate the state and the evolution of the Mediterranean domain. The simulations are conducted in the frame of the Mediterranean coordinated experiment MedCORDEX (Ruti et al. 2015) and supported by the HyMeX program (Drobinski et al. 2014). The simulations use the RCSMs and are intended to reproduce in a model the functioning of the Mediterranean region including for most of them the sea, the atmosphere, the land and the river components. The added-value of this new set of simulations is the use of such multi-component models with high resolution downscaled atmospheric conditions. In this paper we use the results from this new data set to characterize the mean values and long term changes of the heat budget components of the Mediterranean Sea. The results are compared to available observations and to previous simulations. The goal is twofold: on one hand we want to analyse the similarities and discrepancies among the Med-CORDEX ensemble and to do a first assessment of the quality of the model results; on the other hand we want to identify which is the main source of uncertainty responsible for the model spread in terms of the basin average temperature.

The paper is organised as follows: the next section summarizes the models and the simulations used in the study; a detailed description is given in the 'Appendix'. Section 3 presents mean values and trends of the heat budget components from the simulations with a comparison to available observations. Section 4 discusses the impacts of model similarities and differences on the results. The major conclusions of this paper are presented in Sect. 5.

\section{Models and data used}

The Med-CORDEX data used in this study are RCSM outputs from six coupled models all forced laterally by the ERA-Interim reanalyses and six ocean forced models that use dynamically downscaled versions of ERA40/ERAInterim reanalyses as surface forcing. The simulations cover the Mediterranean region and the entire data set is available from the Med-CORDEX data base (www.medcordex.eu/medcordex.php). The models used and the simulations performed are detailed in the 'Appendix'.

The simulated temperature time series are compared to two observational data sets based on in situ profiles. The first set is the RIXEN gridded data set (Rixen et al. 2005). It provides a reconstruction of the Mediterranean Sea temperature for the period $1950-2000$ on a $0.2^{\circ} \times 0.2^{\circ}$ grid using a variational inverse model. Formal errors at each grid point were obtained from this approach (Rixen et al. 2001). The second one is EN4 (EN4.0.1, Good et al. 2013). It is an update of EN3 (Ingleby and Huddleston 2007) obtained by optimal interpolation on a $1^{\circ} \times 1^{\circ}$ grid. The data used cover the period 1910-2013. The basin averaged temperature and its uncertainty for these two data sets are obtained by averaging the temperature and its uncertainty at each data grid point over the Mediterranean Sea volume.

The quantitative comparison between model outputs and observations use simple statistics. The period 1980-2010 common to most data sets is considered as a reference period. However some simulations start after 1980 or end before 2010. In this case the statistics are performed based on the shorter simulated period. Time averages are shown with their $95 \%$ confidence intervals and with significance tests (null hypothesis of zero mean). Significance tests are also shown for correlations at the same confidence level (null hypothesis of absence of correlation). The statistics also include trends, their $95 \%$ level confidence intervals and significance tests (null hypothesis of trend absence) using the two-tailed Mann-Kendall test (Mann 1945; Kendall 1975). The heat content rate is calculated from the time derivative of the basin average temperature yearly values using a constant water density. 
Fig. 1 Annual series of the average temperature over the Mediterranean Sea $\left({ }^{\circ} \mathrm{C}\right)$ from the Med-CORDEX simulations. Series from the two observational products (RIXEN and EN4) are also shown with their associated uncertainty (shaded areas)

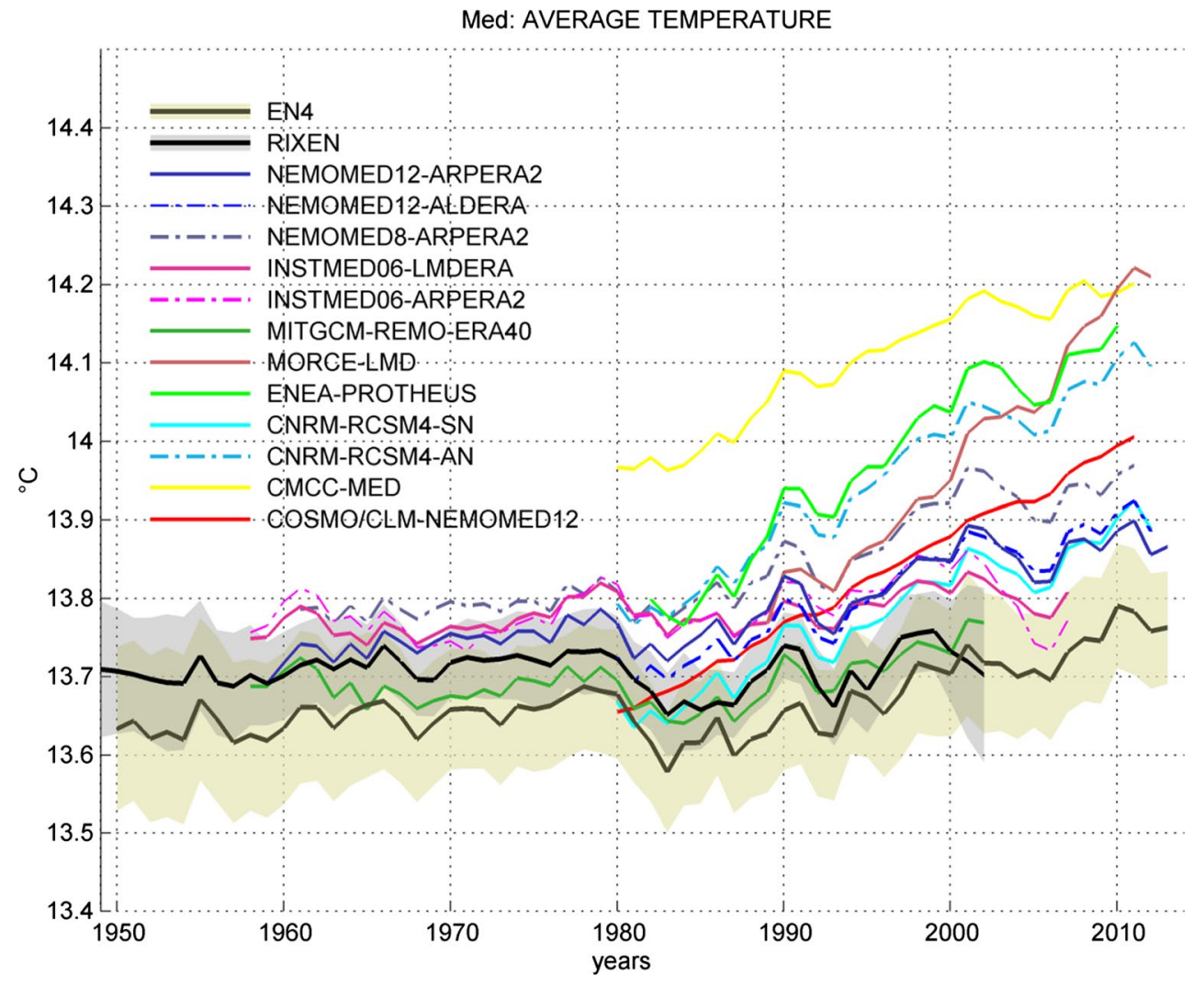

\section{The heat budget components}

\subsection{The basin average temperature}

The average temperature over the basin volume is one of the most important parameters that permit to investigate the state and the evolution of the Mediterranean Sea. The temporal evolution of the average temperature from MedCORDEX models and Rixen and EN4 observational products are shown in Fig. 1. The corresponding mean values over the reference period 1980-2010 are summarized in Table 2. Most models show a significant positive bias relative to observations in particular at the end of the simulated period. Without considering CMCC-MED, the bias in the mean value is less than $\sim 0.1{ }^{\circ} \mathrm{C}$ in 1980 and increases up to $\sim 0.2{ }^{\circ} \mathrm{C}$ in 2010 . Concerning the variability, most models show similar interannual variations. Noteworthy, the abrupt cooling during 1980-1985, 1991-1993 and 2002-2005 and the sudden warming during 1989-1991 (e.g. Brankart and Pinardi, 2001) are particularly well reproduced. The average correlations with the two observational data sets (using detrended series, not shown) are 0.55 for RIXEN and 0.65 for EN4. On the other hand correlations are larger for the forced models ( 0.60 for RIXEN and 0.73 for EN4) compared to the coupled ones ( 0.50 for RIXEN and 0.57 for EN4). As it will be shown below this illustrates the stronger constraints set in the forced models.
Time series of the simulated average temperature clearly show positive trends during the period 1980-2010. The trend estimates from model results and observations are shown in Table 4. All trends are positive and, except INSTMED06-ARPERA2, are significant at the $95 \%$ level. The simulated trends are higher than the observed ones except those of the two INSTMED06 simulations. The low trends for these two simulations may be related to the use of the correction of atmospheric heat fluxes. Also, these simulations use a monthly climatology rather than monthly varying values when relaxing the sea surface temperature (see the 'Appendix' and Table 1). This induces damping of the surface temperature variations and hence a lowering of the average temperature trend. The ensemble average trend is $+8.1 \times 10^{-3}{ }^{\circ} \mathrm{C}$ year $^{-1}$ which is higher than the reported trends in the western basin, the Inonian Sea and the Levantine Basin, +1.2 to $+3.7 \times 10^{-3}{ }^{\circ} \mathrm{C}$ year $^{-1}$ (Bethoux et al. 1998; Bethoux and Gentili 1996, 1999; Tsimplis and Baker 2000; Manca et al. 2004), although the periods considered are different. On the other side, the coupled simulations show larger trends than the forced ones. The average trend for the coupled models is $+12.1 \times 10^{-3}{ }^{\circ} \mathrm{C}$ year ${ }^{-1}$ while for the forced models it is $+4.3 \times 10^{-3}{ }^{\circ} \mathrm{C}$ year ${ }^{-1}$. Such a difference will be discussed in view of differences in the boundary heat fluxes SHF and GHF. 
Table 1 Description of the Med-CORDEX models used in the present study

\begin{tabular}{|c|c|c|c|c|c|c|}
\hline Model/observation & $\begin{array}{l}\text { Simulation period, } \\
\text { statistics duration }\end{array}$ & $\begin{array}{l}\text { Atmospheric com- } \\
\text { ponent }\end{array}$ & $\begin{array}{l}\text { Ocean component, } \\
\text { initial conditions, } \\
\text { spin-up }\end{array}$ & Strait of Gibraltar & Atlantic side & References \\
\hline \multicolumn{7}{|l|}{ Forced } \\
\hline $\begin{array}{l}\text { NEMOMED12- } \\
\text { ARPERA2 }\end{array}$ & $\begin{array}{l}1959-2013 \\
31\end{array}$ & $\begin{array}{l}\text { ARPERA2 } \\
\text { T: RMO }\end{array}$ & $\begin{array}{l}\text { Nemomed } 12 \\
1 / 14^{\circ}-1 / 18^{\circ}, 50 \mathrm{z} \\
\text { IC }=\text { MEDAT- } \\
\text { LAS-1960 and } \\
\text { RIXEN } \\
(1955-1965) \\
\text { Spin-up }=0\end{array}$ & $\begin{array}{l}\mathrm{GP}=2 \\
\mathrm{DS}=266\end{array}$ & $\begin{array}{l}\text { TS: RMO } \\
\eta: \text { RMC } \\
\text { ( } \eta \text { : RMO: } \\
\text { 2002-2008) } \\
\text { NEC,CAB }\end{array}$ & $\begin{array}{l}\text { Beuvier et al. } \\
\text { (2012) }\end{array}$ \\
\hline $\begin{array}{l}\text { NEMOMED12- } \\
\text { ALDERA }\end{array}$ & $\begin{array}{l}1980-2012 \\
31\end{array}$ & $\begin{array}{l}\text { ALDERA } \\
\text { T: RMO } \\
\text { S: FWC }\end{array}$ & $\begin{array}{l}\text { Nemomed } 12 \\
1 / 14^{\circ}-1 / 18^{\circ}, 75 \mathrm{z} \\
\text { IC }=\text { MEDAT- } \\
\text { LAS-1979 } \\
\text { and RIXEN } \\
(1978-1980) \\
\text { Spin-up }=0\end{array}$ & & $\begin{array}{l}\text { TS } \eta: \text { RMO } \\
\text { NEC,CAB }\end{array}$ & Hamon et al. (2015) \\
\hline $\begin{array}{l}\text { NEMOMED8- } \\
\text { ARPERA2 }\end{array}$ & $\begin{array}{l}1961-2011 \\
31\end{array}$ & $\begin{array}{l}\text { ARPERA2 } \\
\text { T: RMO } \\
\text { S: FWC }\end{array}$ & $\begin{array}{l}\text { Nemomed } 8 \\
1 / 8^{\circ}, 43 \mathrm{z} \\
\text { IC }=\text { MEDATLAS } \\
\text { Spin-up }=15\end{array}$ & $\begin{array}{l}\mathrm{GP}=2 \\
\mathrm{DS}=266\end{array}$ & $\begin{array}{l}\text { TS: RMO } \\
\eta: \text { using EC } \\
\text { EC,CAB }\end{array}$ & $\begin{array}{l}\text { Herrmann et al. } \\
(2010), \\
\text { Beuvier et al. } \\
(2010)\end{array}$ \\
\hline $\begin{array}{l}\text { INSTMED06- } \\
\text { LMDERA }\end{array}$ & $\begin{array}{l}1958-2007 \\
28\end{array}$ & $\begin{array}{l}\text { ERA40 dowscaled } \\
\text { by LMDz } \\
\text { adjusted } \\
\text { TS: RMC }\end{array}$ & $\begin{array}{l}\text { INSTMED06 } \\
\quad(\text { POM) } \\
1 / 6^{\circ}-1 / 36^{\circ}, 27 \mathrm{sig} \\
\text { IC = MODB }\end{array}$ & $\begin{array}{l}\mathrm{GP}=3 \\
\mathrm{DS}=247\end{array}$ & $\begin{array}{l}\text { TS: RMC } \\
\eta \text { : relaxation to } \\
\text { the TS steric sea } \\
\text { level }\end{array}$ & $\begin{array}{l}\text { Alioua and Harzal- } \\
\text { lah (2008), } \\
\text { Harzallah et al. } \\
\text { (2014), }\end{array}$ \\
\hline $\begin{array}{l}\text { INSTMED06- } \\
\text { ARPERA2 }\end{array}$ & $\begin{array}{l}1958-2007 \\
28\end{array}$ & $\begin{array}{l}\text { ERA40 dowscaled } \\
\text { by Arpège- } \\
\text { Climate } \\
\text { adjusted } \\
\text { TS: RMC }\end{array}$ & Spin-up $=30$ & & $\mathrm{OAB}$ & $\begin{array}{l}\text { Gualdi et al. } \\
\text { (2013b) }\end{array}$ \\
\hline $\begin{array}{l}\text { MITGCM-REMO- } \\
\text { ERA40 }\end{array}$ & $\begin{array}{l}1958-2002 \\
23\end{array}$ & $\begin{array}{l}\text { ERA40 dowscaled } \\
\text { by REMO } \\
\text { T: RMO } \\
\text { S: RMC }\end{array}$ & $\begin{array}{l}\text { MIT-gcm } \\
1 / 12^{\circ}, 72 \mathrm{z} \\
\text { IC }=\text { MEDATLAS } \\
\text { Spin-up }=0\end{array}$ & $\begin{array}{l}\text { WGP }=3 \\
\mathrm{DS}=266\end{array}$ & $\begin{array}{l}\text { TS: RMC } \\
\text { (Levitus) } \\
\eta: \text { not variable }\end{array}$ & Llasses et al. (2016) \\
\hline \multicolumn{7}{|l|}{ Coupled } \\
\hline MORCE-LMD & $\begin{array}{l}1989-2012 \\
22\end{array}$ & $\begin{array}{l}\text { WRF } \\
\text { ERA-interim }\end{array}$ & $\begin{array}{l}\text { NemoMed12 } \\
1 / 14^{\circ}-1 / 18^{\circ}, 50 \mathrm{z} \\
\mathrm{IC}=\mathrm{MODB} \\
\text { spin-up }=0\end{array}$ & $\begin{array}{l}\text { WGP }=2 \\
D S=266\end{array}$ & $\begin{array}{l}\text { TS: RMC } \\
\text { Levitus } \\
\eta: \text { RMO } \\
\text { NEC,CAB }\end{array}$ & $\begin{array}{l}\text { Drobinski et al. } \\
\text { (2012) }\end{array}$ \\
\hline $\begin{array}{l}\text { ENEA-PRO- } \\
\text { THEUS }\end{array}$ & $\begin{array}{l}1982-2010 \\
29\end{array}$ & $\begin{array}{l}\text { Reg-CM3 } \\
\text { ERA-interim } \\
\text { S: virtual salt flux }\end{array}$ & $\begin{array}{l}\text { MIT-gcm } \\
1 / 8^{\circ}, 42 \mathrm{z} \\
\text { IC }=\text { MEDATLAS } \\
\text { Spin-up = 3D TS } \\
\text { relaxation to } \\
\text { MEDATLAS, } \\
\text { year } 1958 \text { forc- } \\
\text { ing }\end{array}$ & $\begin{array}{l}\text { WGP }=3 \\
\text { DS }=290\end{array}$ & $\begin{array}{l}\text { TS: RMC } \\
\text { (Levitus) } \\
\eta: \text { not variable } \\
\text { EC, CAB }\end{array}$ & Artale et al. (2010) \\
\hline $\begin{array}{l}\text { CNRM-RCSM4- } \\
\text { SN }\end{array}$ & $\begin{array}{l}1980-2012 \\
31\end{array}$ & $\begin{array}{l}\text { Aladin-Climate } \\
\text { and spectral } \\
\text { nudging } \\
\text { ERA-interim }\end{array}$ & $\begin{array}{l}\text { Nemomed8 } \\
1 / 8^{\circ}, 43 \mathrm{z} \\
\mathrm{IC}=\text { MEDATLAS } \\
\text { spin-up }=5+21\end{array}$ & $\begin{array}{l}\text { WGP }=2 \\
D S=266\end{array}$ & $\begin{array}{l}\text { TS } \eta: \text { RMO } \\
\text { NEC, CAB }\end{array}$ & Sevault et al. (2014) \\
\hline $\begin{array}{l}\text { CNRM-RCSM4- } \\
\text { AN }\end{array}$ & $\begin{array}{l}1980-2012 \\
31\end{array}$ & $\begin{array}{l}\text { Aladin-Climate } \\
\text { ERA-interim }\end{array}$ & (3X1980-1986) & & & \\
\hline CMCC-MED & $\begin{array}{l}1980-2011 \\
31\end{array}$ & $\begin{array}{l}\text { COSMO-CLM } \\
\text { ERA-interim }\end{array}$ & $\begin{array}{l}\text { Med: Nemo-MFS } \\
1 / 16^{\circ} 17 \mathrm{z} \\
\text { IC }=\text { MEDATLAS } \\
\text { spin-up }=25 \\
(3 \times 1979-1986)\end{array}$ & $\begin{array}{l}\text { WGP }=3 \\
\mathrm{DS}=323\end{array}$ & $\begin{array}{l}\text { TSn: RMC } \\
\text { UV: RMC } \\
\text { NEC, OAB }\end{array}$ & $\begin{array}{l}\text { Gualdi et al. } \\
\text { (2013b), } \\
\text { Sanna et al. (2013) }\end{array}$ \\
\hline
\end{tabular}


Table 1 continued

\begin{tabular}{|c|c|c|c|c|c|c|}
\hline Model/observation & $\begin{array}{l}\text { Simulation period, } \\
\text { statistics duration }\end{array}$ & $\begin{array}{l}\text { Atmospheric com- } \\
\text { ponent }\end{array}$ & $\begin{array}{l}\text { Ocean component, } \\
\text { initial conditions, } \\
\text { spin-up }\end{array}$ & Strait of Gibraltar & Atlantic side & References \\
\hline $\begin{array}{l}\text { COSMO/CLM- } \\
\text { NEMOMED12 }\end{array}$ & $\begin{array}{l}1980-2011 \\
31\end{array}$ & $\begin{array}{l}\text { COSMO-CLM } \\
\text { ERA-interim }\end{array}$ & $\begin{array}{l}\text { NemoMed } 12 \\
1 / 14^{\circ}-1 / 18^{\circ}, 50 \mathrm{z} \\
\text { IC }=\text { MEDATLAS } \\
\text { Spin-up }=25\end{array}$ & $\begin{array}{l}\text { WGP }=2 \\
D S=266\end{array}$ & $\begin{array}{l}\text { TS } \eta: \text { RMO } \\
\text { NEC,CAB }\end{array}$ & Akhtar et al. (2014) \\
\hline \multicolumn{7}{|l|}{ Observation } \\
\hline RIXEN & $\begin{array}{l}1945-2002 \\
23\end{array}$ & & & & & Rixen et al. (2005) \\
\hline EN4 & $\begin{array}{l}1910-2013 \\
31\end{array}$ & & & & & Good et al. (2013) \\
\hline
\end{tabular}

Columns successively show the name of the model, the period of the simulation with the number of years considered in the statistics, the atmospheric component, the ocean component, the geometry of the Strait of Gibraltar, the Atlantic side parameterizations and model references. The last two lines correspond to the gridded observations used in the study

Acronyms used are: $z$ (sig) number of vertical levels on z (sigma) coordinate; TS $\eta$ corrections applied to the temperature, salinity and sea level; $R M O$ relaxation to monthly varying observations, $R M C$ relaxation to monthly climatology (toperpetual values); $F W C$ freshwater flux correction; $O A B$ Open Atlantic Barrier permitting mass exchange; $C A B$ Closed Atlantic Barrier; $E C$ (NEC): equilibrium (no equilibrium) condition between sea level and net water loss at the Mediterranean sea surface; WGP number of grid points representing the Strait of Gibraltar width; $D S$ Depth of the Strait of Gibraltar sill. IC Initial conditions; Spin-up: number of years used for the model spin-up. MEDATLAS is Mediterranean Sea climatology (MEDAR/MEDATLAS Group 2002)

\subsection{Surface heat flux and heat content rate}

In order to get insights into the processes that lead to the spread among models we look at the different components in the right hand side of (1). The mean net heat flux at the sea surface varies between -4.8 and $+2.2 \mathrm{Wm}^{-2}$. On average, coupled models simulate lower heat loss than forced models (the average value of the net heat flux at the sea surface is $-0.7 \mathrm{Wm}^{-2}$ for coupled models while it is $-4.1 \mathrm{Wm}^{-2}$ for the forced ones). This result is in agreement with the stronger warming simulated by the coupled models and partly explains the corresponding higher temperature trends shown in Table 4. The time series of the net heat flux at the sea surface and the heat content rate from the different models are shown in Fig. 2a, b, respectively. For the net heat flux, apart from differences in the mean values, interannual variations are similar (interproduct correlations range from 0.8 to 0.95 ). Such a high resemblance is attributed to that the same atmospheric fields (ERA40/ ERA-Interim) are used as atmospheric boundary conditions in all the simulations (see Sect. 2). For the heat content rate the resemblance between models is similarly high. In addition the correlations with the observational products also show high values, $\sim 0.7$ for RIXEN and $\sim 0.8$ for EN4 and all series are most of the time within the confidence interval of these two observational data sets (Fig. 2b). It is also important to note that variations of the heat content rate closely follow those of the net heat flux at the sea surface. The correlation between both variables ranges between 0.4 and 0.7 (Table 3) in most of the simulations with a mean value of 0.53 . Variations of the heat content rate show higher correlations with the net heat flux at the sea surface in coupled models $(0.59)$ than in forced ones (0.48). At the opposite, correlations of the heat content rate with observations are higher in forced models ( 0.68 vs. 0.61 for Rixen and 0.78 vs. 0.69 for EN4). Hence compared to coupled modes, forced models simulate heat content rate variations closer to observations but less coherent with the surface fluxes. This may be related to the relaxation procedure in the forced models, which brings the simulated sea surface temperatures to values closer to the observed ones, hence not necessary coherent with the surface fluxes.

Trends of the net heat flux at the sea surface and of the heat content rate (i.e. acceleration of the heat content) are shown in Table 4. Although most trends are not significantly different from zero at the $95 \%$ level, it is useful to examine if there are similarities in the different models. The net heat flux at the sea surface shows that the sign and magnitude of the trends differ among models. At the opposite, most models show positive trends of the heat content rate in agreement with the two gridded observation data sets. The average trend from the simulations is $+58 \times 10^{-3} \mathrm{Wm}^{-2}$ year $^{-1}$ which is close to the trend value form the RIXEN data set, $+52 \times 10^{-3} \mathrm{Wm}^{-2}$ year $^{-1}$ and lower than the trend value from the EN4 data set, $+188 \times 10^{-3} \mathrm{Wm}^{-2}$ year $^{-1}$.

\subsection{Role of the exchanges at the Strait of Gibraltar}

For the Strait of Gibraltar, all models simulate a positive and significant (at the $95 \%$ level) net heat gain (Table 2). Values range between +1.4 and $+6.7 \mathrm{Wm}^{-2}$ 
Table 2 Mediterranean Sea mean temperature and heat budget components from the Med-CORDEX simulations and from previous estimates

\begin{tabular}{|c|c|c|c|c|c|c|c|c|}
\hline & $\begin{array}{l}\text { Model/observa- } \\
\text { tions }\end{array}$ & $T$ & $\frac{\Delta H C}{\Delta t}$ & SHF & $G H F$ & $G H F_{I N}$ & $G H F_{\text {OUT }}$ & SHF-err. \\
\hline \multirow[t]{6}{*}{ Forced models } & $\begin{array}{l}\text { NEMOMED12- } \\
\text { ARPERA2 }\end{array}$ & $13.81 \pm 0.02$ & $+0.74 \pm 1.35$ & $-4.76 \pm 1.68$ & $+5.66 \pm 0.12$ & $+20.19 \pm 0.30$ & $-14.53 \pm 0.23$ & -0.16 \\
\hline & $\begin{array}{l}\text { NEMOMED12- } \\
\text { ALDERA }\end{array}$ & $13.80 \pm 0.02$ & $+1.25 \pm 1.13$ & $-4.02 \pm 1.61$ & $+5.41 \pm 0.15$ & $+19.52 \pm 0.35$ & $-14.11 \pm 0.25$ & -0.14 \\
\hline & $\begin{array}{l}\text { NEMOMED8- } \\
\text { ARPERA2 }\end{array}$ & $13.87 \pm 0.02$ & $+0.93 \pm 1.28$ & $-2.86 \pm 1.74$ & $+5.51 \pm 0.18$ & $+23.73 \pm 0.37$ & $-18.22 \pm 0.25$ & -1.73 \\
\hline & $\begin{array}{l}\text { INSTMED06- } \\
\text { LMDERA }\end{array}$ & $13.79 \pm 0.01$ & $+0.18 \pm 1.11$ & $-4.66 \pm 1.56$ & $+4.05 \pm 0.09$ & $+14.52 \pm 0.13$ & $-10.48 \pm 0.09$ & +0.80 \\
\hline & $\begin{array}{l}\text { INSTMED06- } \\
\text { ARPERA2 }\end{array}$ & $13.80 \pm 0.01$ & $-0.15 \pm 1.66$ & $-4.63 \pm 1.99$ & $+3.63 \pm 0.09$ & $+14.53 \pm 0.18$ & $-10.15 \pm 0.14$ & +0.84 \\
\hline & $\begin{array}{l}\text { MIT- } \\
\text { GCM-REMO- } \\
\text { ERA40 }\end{array}$ & $13.70 \pm 0.02$ & $+0.77 \pm 1.41$ & $-3.72 \pm 2.72$ & $+5.48 \pm 0.19$ & $+20.12 \pm 0.29$ & $-14.63 \pm 0.23$ & -1.00 \\
\hline \multirow[t]{6}{*}{ Coupled models } & MORCE-LMD & $13.96 \pm 0.06$ & $+4.36 \pm 1.73$ & $+2.15 \pm 2.37$ & $+1.44 \pm 0.08$ & $+14.89 \pm 0.32$ & $-13.44 \pm 0.34$ & +0.77 \\
\hline & $\begin{array}{l}\text { ENEA-PRO- } \\
\text { THEUS }\end{array}$ & $13.97 \pm 0.05$ & $+2.26 \pm 1.68$ & $-1.01 \pm 1.90$ & $+5.81 \pm 0.14$ & $+32.38 \pm 0.44$ & $-26.57 \pm 0.44$ & -2.54 \\
\hline & $\begin{array}{l}\text { CNRM-RCSM4- } \\
\text { SN }\end{array}$ & $13.77 \pm 0.03$ & $+1.59 \pm 1.19$ & $-3.50 \pm 1.65$ & $+6.74 \pm 0.20$ & $+24.30 \pm 0.48$ & $-17.56 \pm 0.33$ & -1.66 \\
\hline & $\begin{array}{l}\text { CNRM-RCSM4- } \\
\text { AN }\end{array}$ & $13.94 \pm 0.04$ & $+2.10 \pm 1.16$ & $-2.63 \pm 1.66$ & $+6.56 \pm 0.19$ & $+24.01 \pm 0.41$ & $-17.45 \pm 0.30$ & -1.83 \\
\hline & CMCC-MED & $14.09 \pm 0.03$ & $+1.56 \pm 0.84$ & $-0.19 \pm 1.26$ & $+3.29 \pm 0.16$ & $+22.32 \pm 0.31$ & $-19.00 \pm 0.26$ & -1.54 \\
\hline & $\begin{array}{l}\text { COSMO/CLM- } \\
\text { NEMOMED12 }\end{array}$ & $13.82 \pm 0.04$ & $+2.25 \pm 0.31$ & $+1.08 \pm 1.15$ & $+5.01 \pm 0.17$ & $+22.37 \pm 0.65$ & $-17.35 \pm 0.50$ & -3.85 \\
\hline All models & $\begin{array}{l}\text { ENSEMBLE } \\
\text { MEAN }\end{array}$ & 13.86 & +1.49 & -2.40 & +4.88 & +21.07 & -16.12 & -1.00 \\
\hline \multirow{10}{*}{$\begin{array}{l}\text { Observational } \\
\text { products and } \\
\text { previous simu- } \\
\text { lations }\end{array}$} & RIXEN & $13.70 \pm 0.01$ & $-0.24 \pm 1.57$ & & & & & \\
\hline & EN4 & $13.67 \pm 0.02$ & $+0.68 \pm 1.30$ & & & & & \\
\hline & $\begin{array}{l}\text { Garrett et al. } \\
\text { (1993) }\end{array}$ & & & & $+7 \pm 3$ & & & \\
\hline & $\begin{array}{l}\text { Macdonald et al. } \\
\text { (1994) }\end{array}$ & & & & $+5.2 \pm 1.3$ & & & \\
\hline & $\begin{array}{l}\text { Astraldi et al. } \\
\text { (1999) }\end{array}$ & & & & +5.0 & +32.3 & -27.2 & \\
\hline & $\begin{array}{l}\text { HB combination } \\
\text { (Sanchez-Gomez } \\
\text { et al. 2011) }\end{array}$ & & & $\begin{array}{l}+9 \pm 8 \\
\quad+5 \pm 5 \\
-3 \pm 8\end{array}$ & & & & \\
\hline & $\begin{array}{l}\text { ERA40 } \\
\text { (Sanchez-Gomez } \\
\quad \text { et al. 2011) }\end{array}$ & & & $-15 \pm 6$ & & & & \\
\hline & $\begin{array}{l}\text { ERA40 } \\
\text { corrected } \\
\text { (Pettenuzzo } \\
\text { et al. 2010) }\end{array}$ & & & -7 & & & & \\
\hline & ENSEMBLES & & & $\begin{array}{l}-9 . \pm 21 \\
{[-40 \text { to }+21]}\end{array}$ & & & & \\
\hline & CIRCE & & & $\begin{array}{l}-3.8 \\
{[-6 \text { to }-2]}\end{array}$ & $\begin{array}{l}+4.3 \\
{[+2.3 \text { to }+6.4]}\end{array}$ & $\begin{array}{l}+19.6 \\
{[10.4 \text { to } 31.7]}\end{array}$ & $\begin{array}{l}-15.3 \\
{[6.4 \text { to } 25.4]}\end{array}$ & \\
\hline
\end{tabular}

The columns successively show the average temperature $\left({ }^{\circ} \mathrm{C}\right)$, the heat content rate, the net heat flux at the sea surface, the net, the inward and the outward heat fluxes through the Strait of Gibraltar and the residual heat flux $\left(\frac{\Delta H C}{\Delta t}-S H F-G H F\right)$. All fluxes are in Wm ${ }^{-2}$. The period considered for the Med-CORDEX simulations is 1980-2010 with some exceptions (see Table 1 for details). The confidence limits at the $95 \%$ level for mean values estimates are also shown. Estimates for which the zero mean hypothesis is rejected (not rejected) at the $95 \%$ level are shown in bold (italic). Numbers between square brackets indicate the estimate range. See text for more details on the estimates by Sanchez-Gomez et al. (2011) and Pettenuzzo et al. (2010) 
Table 3 Correlation coefficients between the heat content rate and the net heat flux at the sea surface and between the heat content rate and the net heat flux at the Strait of Gibraltar based on the Med-CORDEX simulations

\begin{tabular}{|c|c|c|c|}
\hline & Model & $\frac{\Delta H C}{\Delta t} \times S H F$ & $\frac{\Delta H C}{\Delta t} \times G H F$ \\
\hline \multirow[t]{6}{*}{ Forced models } & $\begin{array}{l}\text { NEMOMED12-ARP- } \\
\text { ERA2 }\end{array}$ & +0.63 & +0.38 \\
\hline & $\begin{array}{l}\text { NEMOMED12- } \\
\text { ALDERA }\end{array}$ & +0.48 & +0.40 \\
\hline & $\begin{array}{l}\text { NEMOMED8-ARP- } \\
\text { ERA2 }\end{array}$ & +0.57 & +0.28 \\
\hline & $\begin{array}{l}\text { INSTMED06- } \\
\text { LMDERA }\end{array}$ & +0.36 & +0.19 \\
\hline & $\begin{array}{l}\text { INSTMED06-ARP- } \\
\text { ERA2 }\end{array}$ & +0.47 & -0.26 \\
\hline & $\begin{array}{l}\text { MITGCM-REMO- } \\
\text { ERA40 }\end{array}$ & +0.39 & +0.32 \\
\hline \multirow[t]{6}{*}{ Coupled models } & $\begin{array}{l}\text { MORCE-LMD- } \\
\text { ERAINT }\end{array}$ & +0.69 & -0.04 \\
\hline & ENEA-PROTHEUS & +0.65 & -0.17 \\
\hline & $\begin{array}{l}\text { CNRM-RCSM4 -SN- } \\
\text { ERAINT }\end{array}$ & +0.55 & +0.36 \\
\hline & $\begin{array}{l}\text { CNRM-RCSM4 -AN- } \\
\text { ERAINT }\end{array}$ & +0.48 & +0.41 \\
\hline & CMCC-MED & +0.55 & +0.22 \\
\hline & $\begin{array}{l}\text { COSMO/CLM- } \\
\text { NEMOMED12 }\end{array}$ & +0.55 & +0.26 \\
\hline
\end{tabular}

The period considered is 1980-2010 with some exceptions (see Table 1 for details). Estimates for which a non-significant correlation is rejected (not rejected) at the $95 \%$ level are shown by bold (italic)

with a mean value of $+4.9 \mathrm{Wm}^{-2}$ and no significant differences between coupled and forced models. Looking at the mean inward and outward heat fluxes there is a rather important spread between models. The mean values range between +14.5 and $+32.4 \mathrm{Wm}^{-2}$ for the inward heat flux and between -10.2 and $-26.6 \mathrm{Wm}^{-2}$ for the outward heat flux. It is worth noting that the exchanged fluxes are larger in the coupled models than in the forced ones; the mean inward flux is $+23.4(+18.8) \mathrm{Wm}^{-2}$ and the mean outward flux is $-18.6(-13.8) \mathrm{Wm}^{-2}$ for the coupled (forced) models. It is interesting to note the relatively weak interannual variability of the modelled heat flux at the Strait of Gibraltar; the ensemble average annual standard deviation (std) is $0.4 \mathrm{Wm}^{-2}$ while it is $4.7 \mathrm{Wm}^{-2}$ for the net heat flux at the sea surface. This is in agreement with the weak variability shown by Astraldi et al. (1999) in a nearly two-year heat flux series. The time series of the heat fluxes at the Strait are shown in Fig. 3. For most models the simulations show different time evolutions even for the net heat flux (Fig. 3c). In opposition to the high correlations between the heat content rate and the net heat flux at the sea surface, most correlations between the heat content rate and the net heat flux at the Strait of Gibraltar (Table 3) are not significant except for the NEMOMED12 and the CNRM-RCSM4 simulations. It would be interesting to further examine the reasons for such significant correlations for these two simulations in particular the dependence on the 3D temperature distribution inside the basin.

The model results show large differences in the simulated heat fluxes at the Strait of Gibraltar. More insight can be gained looking at what determines these fluxes: the water flux and the temperature of the exchanged masses. Mean values of the water fluxes at the Strait of Gibraltar are shown in Table 5. All models, except MORCE-LMD show very close net water fluxes ranging from +0.042 to $+0.076 \mathrm{~Sv}$. It is worth recalling that the net water flux at the Strait is mainly determined by the net water flux through the Mediterranean Sea surface which equals the difference between the evaporation and the precipitation (E-P). This quantity is provided in all models by a downscaling of ERA40/ERA-Interim fields. The low values in MORCE-LMD are due to an excess of precipitation over evaporation. The inward and outward fluxes show a larger spread (ranging from +0.44 to $+1.08 \mathrm{~Sv}$ for the inflow and -0.45 to $-1.02 \mathrm{~Sv}$ for the outflow). Although these values are within the generally accepted values, they can be up to a $20 \%$ higher or lower than recent estimates based on observations (e.g., +0.81 and $-0.78 \mathrm{~Sv}$ for the inflow and outflow, respectively; Soto-Navarro et al. 2010). The relatively low values simulated by the two INSTMED06 simulations are probably due to the limited depth of the Strait of Gibraltar which reduces the area across the Strait and thus reduces the exchanged transport.

Time series of the simulated water fluxes at the Strait of Gibraltar are shown in Fig. 4. Corresponding series reconstructed from the observations made at the Strait for the period 2004-2010 (Jordà et al. 2016) are also shown. The length of the observations (6 years) prevents drawing any conclusion, but a first comparison suggests higher fluxes in the observational products. The time evolution of the inward and outward water fluxes (Fig. 4a, b) closely resemble the corresponding ones for the heat fluxes (Fig. 3a, b) and also show no significant correlations among the different models. In opposition to the net heat flux (Fig. 3c) the net water flux (Fig. 4c) shows highly coherent series (expect for a shift of series for the MORCE-LMD model). This was somehow expected for the forced models, as far as the net water flux at the sea surface is derived from a downscaling of the same reanalysis. Interestingly, the coupled models also reproduce similar net water flux series as the forced ones.

Table 5 shows the mean temperature values obtained dividing inward and outward heat fluxes by the corresponding water fluxes. This provides the equivalent average temperatures of the inflowing and outflowing water masses. 
Table 4 Trend estimates of the Mediterranean Sea average temperature and of the heat budget components from the Med-CORDEX simulations and from previous estimates

\begin{tabular}{|c|c|c|c|c|c|c|c|}
\hline & Model/observations & $T$ & $\frac{\Delta H C}{\Delta t}$ & SHF & $G H F$ & $G H F_{I N}$ & $G H F_{\text {OUT }}$ \\
\hline \multirow[t]{6}{*}{ Forced models } & $\begin{array}{l}\text { NEMOMED12- } \\
\text { ARPERA2 }\end{array}$ & $+5.1 \pm 1.1$ & $+62.4 \pm 152.1$ & $+52.5 \pm 190.7$ & $+6.1 \pm 13.8$ & $+26.9 \pm 32.0$ & $+20.8 \pm 25.0$ \\
\hline & $\begin{array}{l}\text { NEMOMED12- } \\
\text { ALDERA }\end{array}$ & $+7.0 \pm 0.9$ & $+47.0 \pm 127.0$ & $+34.3 \pm 182.9$ & $+14.6 \pm 16.7$ & $+4.7 \pm 39.3$ & $-9.9 \pm 28.5$ \\
\hline & $\begin{array}{l}\text { NEMOMED8- } \\
\text { ARPERA2 }\end{array}$ & $+6.3 \pm 1.1$ & $+52.4 \pm 144.6$ & $+50.9 \pm 197.1$ & $-2.5 \pm 20.7$ & $-1.7 \pm 42.6$ & $+0.8 \pm 28.4$ \\
\hline & $\begin{array}{l}\text { INSTMED06- } \\
\text { LMDERA }\end{array}$ & $+1.4 \pm 0.9$ & $+98.3 \pm 134.2$ & $+43.2 \pm 196.9$ & $+3.9 \pm 11.0$ & $+6.0 \pm 16.8$ & $+2.1 \pm 11.6$ \\
\hline & $\begin{array}{l}\text { INSTMED06-ARP- } \\
\text { ERA2 }\end{array}$ & $+1.0 \pm 1.7$ & $+61.5 \pm 208.7$ & $-35.2 \pm 250.5$ & $-3.4 \pm 11.2$ & $-2.8 \pm 22.5$ & $+0.6 \pm 18.3$ \\
\hline & $\begin{array}{l}\text { MITGCM-REMO- } \\
\text { ERA40 }\end{array}$ & $+5.1 \pm 1.4$ & $+224.2 \pm 193.2$ & $-41.5 \pm 420.7$ & $-3.7 \pm 18.3$ & $-37.5 \pm 41.9$ & $-33.8 \pm 33.0$ \\
\hline \multirow[t]{6}{*}{ Coupled models } & MORCE-LMD & $+19.1 \pm 1.7$ & $+21.4 \pm 279.7$ & $-56.1 \pm 382.8$ & $-15.2 \pm 11.7$ & $+58.6 \pm 44.1$ & $+72.8 \pm 44.3$ \\
\hline & ENEA-PROTHEUS & $+13.5 \pm 1.4$ & $+74.7 \pm 202.6$ & $+57.8 \pm 230.2$ & $-32.3 \pm 11.1$ & $+17.2 \pm 53.6$ & $+49.5 \pm 50.1$ \\
\hline & CNRM-RCSM4-SN & $+8.3 \pm 0.9$ & $+54.1 \pm 134.2$ & $+37.7 \pm 187.3$ & $+23.4 \pm 20.6$ & $+63.8 \pm 48.6$ & $+40.3 \pm 34.8$ \\
\hline & CNRM-RCSM4-AN & $+11.2 \pm 1.0$ & $+40.8 \pm 131.1$ & $+21.9 \pm 188.7$ & $+16.5 \pm 19.8$ & $+50.0 \pm 43.0$ & $+33.5 \pm 31.2$ \\
\hline & CMCC-MED & $+8.7 \pm 0.9$ & $-52.4 \pm 93.6$ & $-3.2 \pm 143.6$ & $-38.5 \pm 11.1$ & $-21.2 \pm 34.2$ & $+17.3 \pm 21.3$ \\
\hline & $\begin{array}{l}\text { COSMO/CLM- } \\
\text { NEMOMED12 }\end{array}$ & $+11.5 \pm 2.3$ & $+10.2 \pm 34.7$ & $+18.4 \pm 131.1$ & $-21.9 \pm 17.9$ & $-23.3 \pm 73.6$ & $-1.42 \pm 56.6$ \\
\hline All models & $\begin{array}{l}\text { ENSEMBLE } \\
\text { MEAN }\end{array}$ & +8.12 & +57.89 & +15.06 & -4.41 & +11.73 & +16.06 \\
\hline \multirow{4}{*}{$\begin{array}{l}\text { Observational prod- } \\
\text { ucts and previous } \\
\text { simulations }\end{array}$} & RIXEN & $+4.1 \pm 1.11$ & $+52.3 \pm 241.2$ & & & & \\
\hline & EN4 & $+2.7 \pm 1.81$ & $+187.7 \pm 137.5$ & & & & \\
\hline & ERA40 & & & $-9.7+111.3$ & & & \\
\hline & $\begin{array}{l}\text { Bethoux et al. } \\
\quad(1998) ; \\
\text { Bethoux and Gentili } \\
\quad(1996,1999) ; \\
\text { Tsimplis and Baker } \\
\quad(2000) \text {; } \\
\text { Manca et al. (2004) }\end{array}$ & {$[+1.2$ to +3.7$]$} & & & & & \\
\hline
\end{tabular}

Trend values are given with their confidence limits at the $95 \%$ level. Trend estimates for which the hypothesis of trend absence is rejected (not rejected) at the $95 \%$ level according to the Mann-Kendall test are shown in bold (italic). The period considered for the Med-CORDEX simulations is 1980-2010 with some exceptions (see Table 1 for details). The columns successively show trends for the average temperature, the heat content rate, the net heat flux at the sea surface and the net, the inward and the outward heat fluxes through the Strait of Gibraltar. Trends are in $10^{-3} \mathrm{Wm}^{-2}$ year $^{-1}$ except for the average temperature which is in $10^{-3}{ }^{\circ} \mathrm{C}$ year ${ }^{-1}$. The ERA40 estimate is obtained based on the ERA40 net heat fluxes at the sea surface for the period 1958-2001. See text for more details on the estimates given in the last line of the table

For the inflow component the temperature corresponds to that of the Atlantic Ocean water entering the Mediterranean Sea. For the outflow component it represents the temperature of the Mediterranean water leaving the basin towards the Atlantic Ocean. Hence the latter is an indication of the Mediterranean basin thermal state at intermediate and deep layers. Most models present a value of the mean temperature of the inflowing water around $\sim 16.8^{\circ} \mathrm{C}$. The ENEA-PROTHEUS and MITGCM-REMO-ERA40 show the highest values, 17.7 and $19.1{ }^{\circ} \mathrm{C}$, respectively whereas MORCE-LMD shows the lowest value, $15.3{ }^{\circ} \mathrm{C}$. These values are strongly determined by the lateral boundary conditions imposed in the Atlantic side. Similarly, the temperature of the leaving water, which is defined by the initial conditions and by the heat redistribution simulated by each model, shows large variations among models. The lowest value is $12.2{ }^{\circ} \mathrm{C}$ for MORCE-LMD and the highest one is $15.4{ }^{\circ} \mathrm{C}$ for ENEA-PROTHEUS. It is interesting to mention that the NEMOMED12-ARPERA2 simulations show lower outflow temperatures compared to the NEMOMED8 in spite of using the same atmospheric forcing. This was already shown by Soto-Navarro et al. (2015) who attributed the lower temperatures in NEMOMED12 to a better representation of the proportion of deep waters in the outflow. Also the CNRM-RCSM4-SN model simulates cooler outflowing water than the CNRM-RCSM4-AN 
Fig. 2 a Annual series of the net heat flux at the sea surface of the Mediterranean Sea based on the Med-CORDEX simulations. b Annual series of the heat content rate in the Mediterranean Sea from the same simulations. Series from the two observational products (RIXEN and EN4) with their associated uncertainty (shaded areas) are also shown. Units are $\mathrm{Wm}^{-2}$

Fig. 3 Annual series of inward (a), outward (b) and net (c) heat fluxes through the Strait of Gibraltar from the MedCORDEX simulations. Units are $\mathrm{Wm}^{-2}$
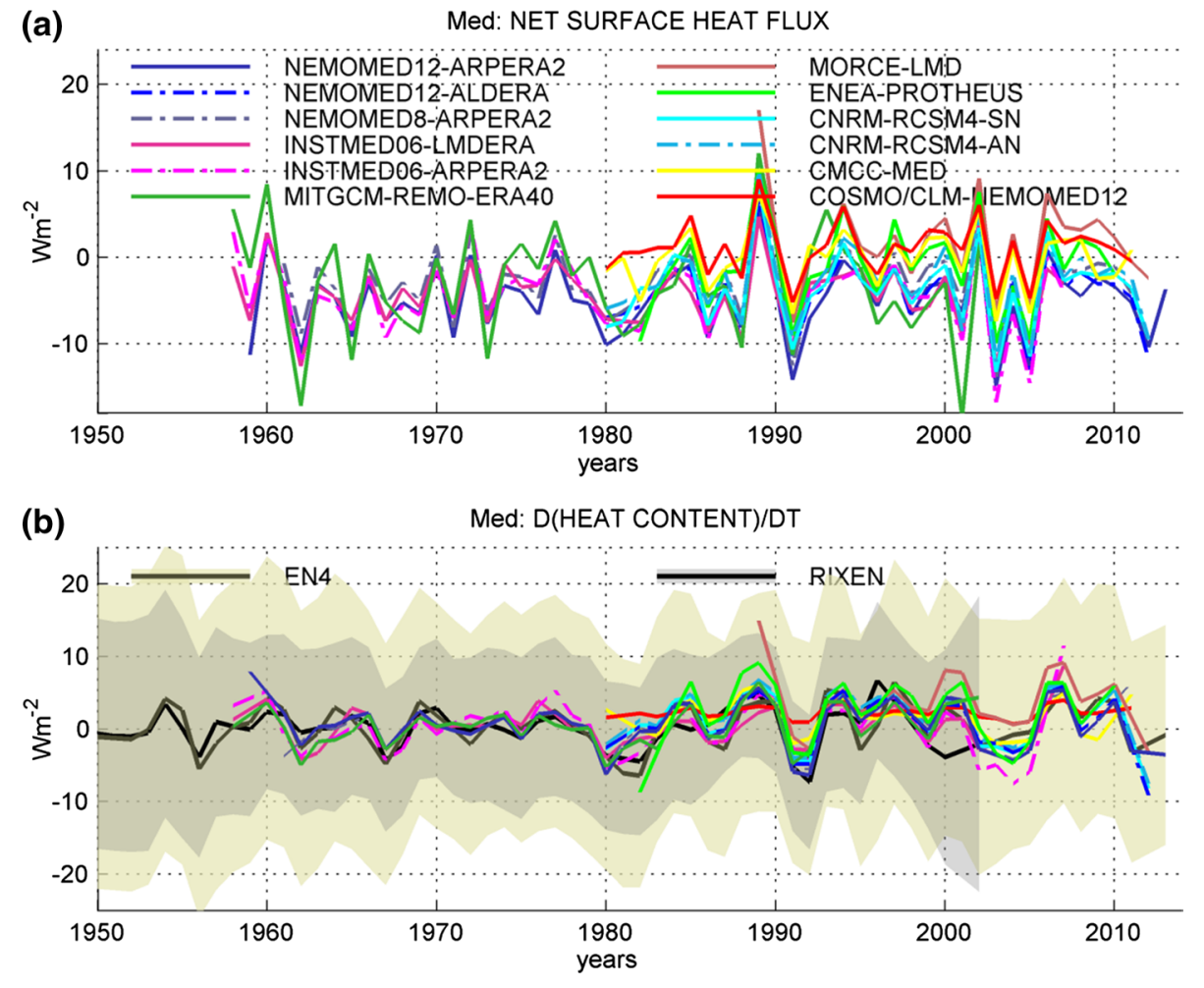

HEAT FLUXES AT THE STRAIT OF GIBRALTAR

\begin{tabular}{|c|c|c|c|}
\hline $\begin{array}{l}-\cdot-\cdot-\cdot- \\
-\cdot \cdot \cdot-\cdot \cdot \\
-\cdot-\cdot-\cdot \cdot \\
\end{array}$ & $\begin{array}{l}\text { NEMOMED12-ARPERA2 } \\
\text { NEMOMED12-ALDERA } \\
\text { NEMOMED8-ARPERA2 } \\
\text { INSTMED06-LMDERA } \\
\text { INSTMED06-ARPERA2 } \\
\text { MITGCM-REMO-ERA40 }\end{array}$ & 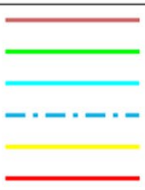 & $\begin{array}{l}\text { MORCE-LMD } \\
\text { ENEA-PROTHEUS } \\
\text { CNRM-RCSM4-SN } \\
\text { CNRM-RCSM4-AN } \\
\text { CMCC-MED } \\
\text { COSMO/CLM-NEMOMED12 }\end{array}$ \\
\hline
\end{tabular}
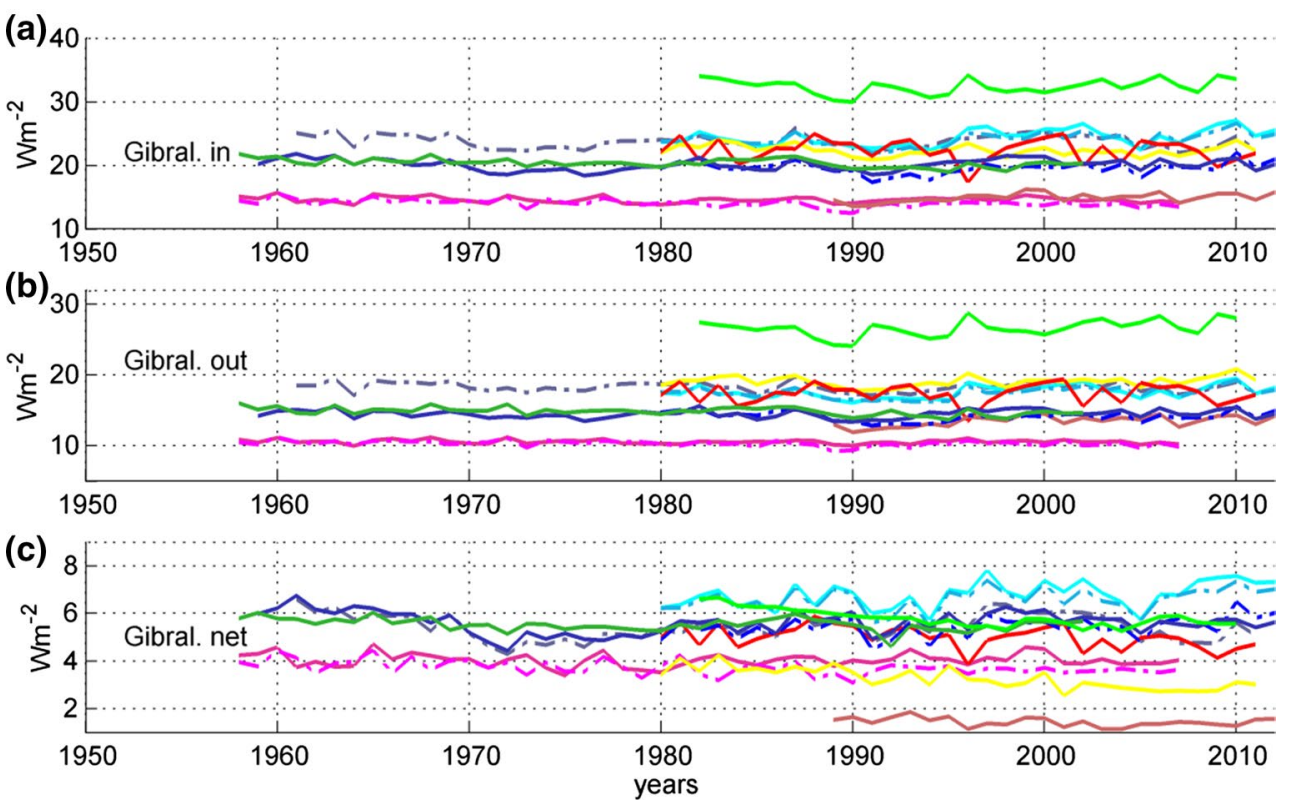
Table 5 Water fluxes and temperatures at the Strait of Gibraltar from the Med-CORDEX simulations and from previous estimates

\begin{tabular}{|c|c|c|c|c|c|c|}
\hline Model & $\phi_{N E T}$ & $\phi_{I N}$ & $\phi_{O U T}$ & $T_{I N}$ & $T_{O U T}$ & $\Delta T_{G I B}$ \\
\hline \multicolumn{7}{|l|}{ Forced models } \\
\hline $\begin{array}{l}\text { NEMOMED12- } \\
\text { ARPERA2 }\end{array}$ & $+0.044 \pm 0.003$ & $+0.72 \pm 0.01$ & $-0.67 \pm 0.01$ & 16.6 & 12.7 & 3.9 \\
\hline $\begin{array}{l}\text { NEMOMED12- } \\
\text { ALDERA }\end{array}$ & $+0.045 \pm 0.004$ & $+0.70 \pm 0.01$ & $-0.66 \pm 0.01$ & 16.8 & 12.7 & 4.1 \\
\hline $\begin{array}{l}\text { NEMOMED8-ARP- } \\
\text { ERA2 }\end{array}$ & $+0.053 \pm 0.002$ & $+0.86 \pm 0.01$ & $-0.81 \pm 0.01$ & 16.3 & 13.4 & 3.0 \\
\hline $\begin{array}{l}\text { INSTMED06- } \\
\text { LMDERA }\end{array}$ & $+0.059 \pm 0.003$ & $+0.51 \pm 0.00$ & $-0.45 \pm 0.00$ & 16.7 & 13.6 & 3.1 \\
\hline $\begin{array}{l}\text { INSTMED06-ARP- } \\
\text { ERA2 }\end{array}$ & $+0.046 \pm 0.004$ & $+0.44 \pm 0.01$ & $-0.39 \pm 0.01$ & 16.8 & 13.4 & 3.4 \\
\hline $\begin{array}{l}\text { MITGCM-REMO- } \\
\text { ERA40 }\end{array}$ & $+0.048 \pm 0.004$ & $+0.62 \pm 0.01$ & $-0.57 \pm 0.01$ & 19.1 & 15.1 & 4.0 \\
\hline \multicolumn{7}{|l|}{ Coupled models } \\
\hline MORCE-LMD & $-0.076 \pm 0.005$ & $+0.57 \pm 0.01$ & $-0.65 \pm 0.02$ & 15.3 & 12.2 & 3.1 \\
\hline ENEA-PROTHEUS & $+0.061 \pm 0.003$ & $+1.08 \pm 0.02$ & $-1.02 \pm 0.02$ & 17.7 & 15.4 & 2.3 \\
\hline CNRM-RCSM4-SN & $+0.052 \pm 0.003$ & $+0.85 \pm 0.01$ & $-0.80 \pm 0.01$ & 16.9 & 13.0 & 3.9 \\
\hline CNRM-RCSM4-AN & $+0.054 \pm 0.004$ & $+0.84 \pm 0.01$ & $-0.78 \pm 0.01$ & 16.9 & 13.2 & 3.7 \\
\hline CMCC-MED & $+0.042 \pm 0.003$ & $+0.84 \pm 0.01$ & $-0.79 \pm 0.01$ & 15.8 & 14.2 & 1.6 \\
\hline $\begin{array}{l}\text { COSMO/CLM- } \\
\text { NEMOMED12 }\end{array}$ & $+0.047 \pm 0.001$ & $+0.79 \pm 0.02$ & $-0.74 \pm 0.02$ & 16.8 & 13.9 & 2.9 \\
\hline \multicolumn{7}{|l|}{ All models } \\
\hline ENSEMBLE MEAN & 0.040 & +0.74 & -0.70 & 16.8 & 13.7 & 3.3 \\
\hline \multicolumn{7}{|c|}{ Observational products and previous simulations } \\
\hline Bryden et al. (1994) & +0.04 & +0.72 & -0.68 & & & \\
\hline Astraldi et al. (1999) & +0.04 & +1.01 & -0.97 & & & \\
\hline $\begin{array}{l}\text { Tsimplis and Bryden } \\
\text { (2000) }\end{array}$ & +0.11 & +0.78 & -0.67 & & & \\
\hline Baschek et al. (2001) & +0.05 & +0.81 & -0.76 & & & \\
\hline $\begin{array}{l}\text { Soto-Navarro et al. } \\
\text { (2010) }\end{array}$ & $+0.038 \pm 0.007$ & $+0.81 \pm 0.06$ & $-0.78 \pm 0.05$ & & & \\
\hline $\begin{array}{l}\text { Bethoux and Gentili } \\
\text { (1999) }\end{array}$ & & & & 15.4 & 13.4 & 2.0 \\
\hline CIRCE & +0.04 & +0.85 & -0.81 & & & \\
\hline
\end{tabular}

The first three columns show mean values of the net, the inward and the outward water fluxes at the Strait of Gibraltar (Sv). Confidence limits at the $95 \%$ level are also shown. The next two columns show the mean temperature $\left({ }^{\circ} \mathrm{C}\right)$ of the inflowing and outflowing waters $($ see text for details). The last column shows the difference of the two previous temperature values. The period considered for the Med-CORDEX simulations is 1980-2010 with some exceptions (see Table 1 for details)

model, in agreement with the lower basin average temperature simulated by the CNRM-RCSM4-SN model shown in Fig. 1. The difference between the mean temperatures of the inflowing and outflowing waters is $\sim 3.2{ }^{\circ} \mathrm{C}$ with the weakest value $\left(1.6^{\circ} \mathrm{C}\right)$ for MORCE-LMD and the highest one for NEMOMED12-ALDERA $\left(4.1^{\circ} \mathrm{C}\right)$. From the observations typical mean values of the temperature at the layers $(0-150 \mathrm{~m})$ and $(150-300 \mathrm{~m})$ are 15.4 and $13.4{ }^{\circ} \mathrm{C}$, respectively. Thus the difference is $2{ }^{\circ} \mathrm{C}$ (Bethoux and Gentili 1999). The inflow and outflow temperatures derived following the same approach but based on the mean water and heat fluxes of Astraldi et al. (1999) give higher values, 19.2 and $16.8{ }^{\circ} \mathrm{C}$ respectively, with a difference of $2.4{ }^{\circ} \mathrm{C}$.
The time series of the temperature of the inflowing water (Fig. 5a) show different behaviours that reflect different approaches used for modelling the Atlantic Ocean zone. The MITGCM-REMO-ERA40, CMCC-MED, MORCE-LMD, ENEA-PROTHEUS and INSTMED06 models show small interannual variability; those models use a relaxation towards the climatology in the Atlantic zone. The remaining models show a rather similar behaviour with a relatively high interannual variability. Those models use a relaxation towards time-varying observed conditions in the Atlantic zone (see Beuvier et al. 2010). The temperature of the outflowing water (Fig. 5b) shows a much weaker interannual variability, a signature of the slowly varying intermediate and deep waters. 

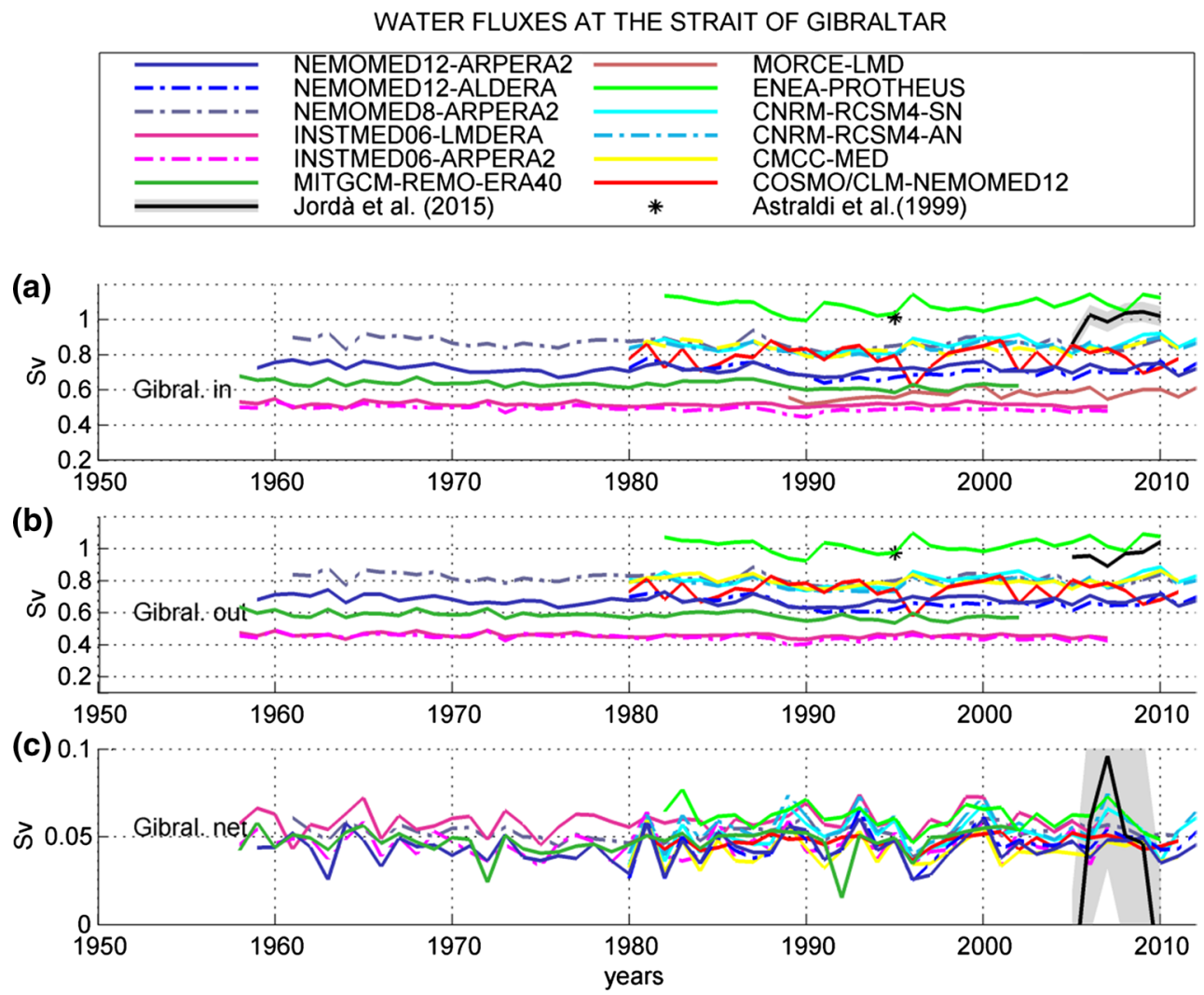

Fig. 4 Annual series of inward (a), outward (b) and net (c) water fluxes through the Strait of Gibraltar from the Med-CORDEX simulations. Units are in $\mathrm{Sv}\left(1 \mathrm{~Sv}=10^{6} \mathrm{~m}^{3} \mathrm{~s}^{-1}\right)$. Estimates based on observations of Astraldi et al. (1999) and from Jordà et al. (2016) are also shown

Trends of the heat and water fluxes at the Strait of Gibraltar are presented in Tables 4 and 6, respectively. The inward and outward fluxes show no coherent trends for both heat and water. Similarly, the net heat flux shows different trend signs, although trends are significant for four coupled models. For the net water flux, although trends are weak and not significant at the $95 \%$ level (except MORCE-LMD), most models (nine) show positive values. The ensemble average is $+0.2 \times 10^{3} \mathrm{~m}^{3} \mathrm{~s}^{-1}$ year $^{-1}$ with values ranging from -0.2 to $+1.3 \times 10^{3} \mathrm{~m}^{3} \mathrm{~s}^{-1}$ year $^{-1}$. Fenoglio-Marc et al. (2013) found an increase in the net water flux at the Strait of Gibraltar of $\sim+0.8 \times 10^{3} \mathrm{~m}^{3} \mathrm{~s}^{-1}$ year $^{-1}$ based on the results from one single model. The net water flux increase was explained by Fenoglio-Marc et al. (2013) as resulting from an increase in the net evaporation at the sea surface which has also been demonstrated by Mariotti (2010) but with a significant multi-decadal variability. Table 6 also shows that most models simulate positive trends of the temperatures of the inflowing and outflowing waters. For the outflowing water the trends are significant for eleven models and the average value is around $+8.4 \times 10^{-3}{ }^{\circ} \mathrm{C}_{\text {year }}{ }^{-1}$ about half the trend estimate of $+15 \times 10^{-3}{ }^{\circ} \mathrm{C}$ year $^{-1}$ proposed by Millot et al. (2006). In agreement with those authors, such temperature increase is suggested to be related to a change of the hydrographic conditions inside the Mediterranean basin.

\section{Discussion}

In opposition to the highly resembling series of the net heat flux at the sea surface (the annual correlations between pairs of simulations are greater than 0.7 for all cases), the agreement on the series of the net heat flux through the Strait of Gibraltar is low and significant correlations $(0.5-0.8)$ are found only between models which are using the same boundary conditions in the Atlantic (namely the NEMOMED8, NEMOMED12 and CNRM models). In order to get an insight of the reasons behind this intermodel spread, we assumed a two layer system in Gibraltar, with Atlantic water flowing towards the Mediterranean in the upper layer and Mediterranean water flowing towards the Atlantic in the lower layer. Thus, we can formulate the net heat flux through the Strait of Gibraltar as

$G H F=\phi_{I N} \Delta T_{G I B}+\phi_{N E T} T_{O U T}$

where $\phi_{I N}$ and $\phi_{N E T}$ are the inward and net water fluxes and $\Delta T_{G I B}=T_{I N}-T_{O U T}$ is the difference of temperatures 
Fig. 5 Annual series of the mean temperature of the inflowing water (a), of the outflowing water (b) and of their difference (c) from the Med-CORDEX simulations. The mean temperatures are deduced from the ratio of the heat and the water fluxes through the Strait of Gibraltar for the inward and outward components. Units are ${ }^{\circ} \mathrm{C}$
EQUIVALENT TEMPERATURE AT THE STRAIT OF GIBRALTAR

\begin{tabular}{|c|c|c|c|}
\hline & NEMOMED12-ARPERA2 & $\longrightarrow$ & MORCE-LMD \\
\hline ロ・ー・ー・: & $\begin{array}{l}\text { NEMOMED12-ALDERA } \\
\text { NEMOMED8-ARPERA2 }\end{array}$ & - & ENEA-PROTHEUS \\
\hline$\overline{-\cdot-\cdot-\cdot \cdot}$ & $\begin{array}{l}\text { INSTMED06-LMDERA } \\
\text { INSTMED06-ARPERA2 }\end{array}$ & -・-・-・- & $\begin{array}{l}\text { CNRM-RCSM4-AN } \\
\text { CMCC-MED }\end{array}$ \\
\hline & MITGCM-REMO-ERA40 & $\longrightarrow$ & COSMO/CLM-NEMOMED12 \\
\hline
\end{tabular}

(a)

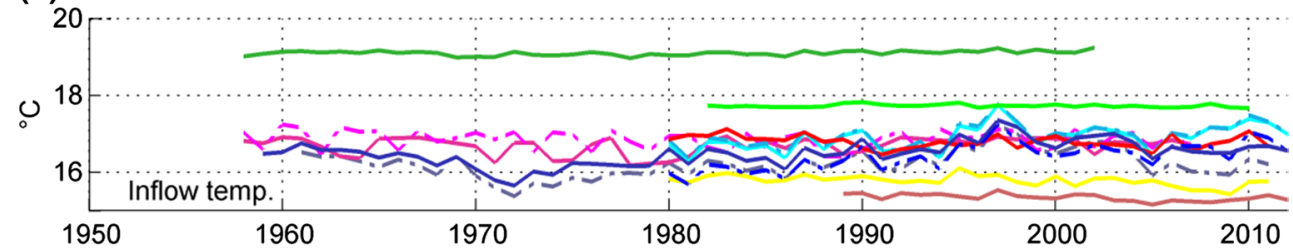

(b)
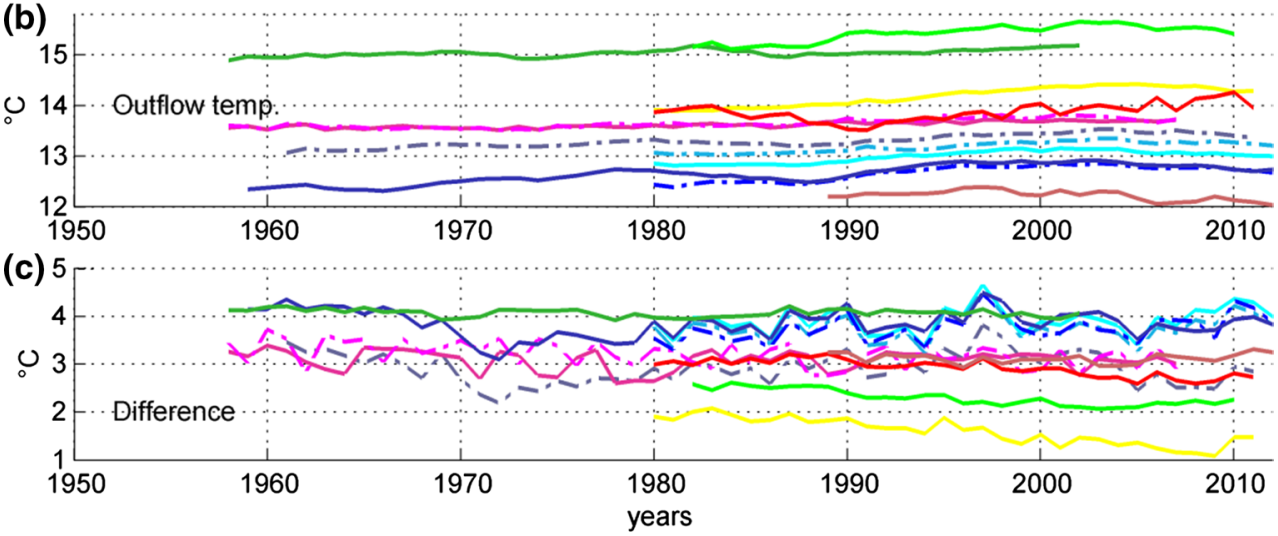

of the inflowing and outflowing waters. Next, we can do a simple estimate of the expected spread in the Strait of Gibraltar heat flux using the intermodel spread of each component (Tables 2, 5) and keeping the rest of the terms constant. Thus, it can be seen that the spread in GHF induced by the spread in $\phi_{I N}$, in $\Delta T_{G I B}$ and in $\phi_{N E T}$ are $0.96,0.92$ and $0.85 \mathrm{Wm}^{-2}$, respectively. The spread induced by the spread in $T_{O U T}$ is only $0.05 \mathrm{Wm}^{-2}$. The spread in $\phi_{I N}$ is related to that in the difference of densities of the inflowing and outflowing waters, mainly due to the model initialization but also to the particular way the Strait is solved. Here the bottom drag and the topography play a key role in determining the exchange transports (e.g. Soto-Navarro et al. 2015). The spread in $\Delta T_{G I B}$ can be associated to the initial state of the models. This can be illustrated in the large $\Delta T_{G I B}$ difference between the NEMOMED12 and NEMOMED8 simulations (Fig. 5c) that foremost results from the difference in $T_{\text {OUT }}$ (Fig. 5b) which is strongly dependent on the initial conditions. The evolution of the temperature inside the basin can also modify $\Delta T_{G I B}$, but the change during the analysed period is very slow. Finally, the spread in the $\phi_{N E T}$ has a strong impact in spite of being relatively small (intermodel std $=0.04 \mathrm{~Sv}$ ). The small intermodel spread in $\phi_{N E T}$ has to be linked to the E-P imposed at the basin surface. It is worth mentioning that the interannual variability of the net water flux $\phi_{N E T}$ is probably underestimated as most analysed models do not include the atmospheric pressure as a forcing variable. Therefore, most models miss the impact of the atmospheric pressure gradient, which is a non-negligible contributor to the interannual variability of the flow through the Strait of Gibraltar (e.g. Gomis et al. 2006).

For most models a significant warming of the outflow is found. Such warming is probably linked to a change in the Mediterranean thermal conditions. It agrees with the warming of the densest Mediterranean outflowing water due to changes in its composition (Millot et al. 2006). The lower basin average temperature and the cooler outflowing water in CNRM-RCSM4-SN compared to CNRM-RCSM4-AN (Tables 2, 5) may reflect an effect of surface fluxes on the thermal conditions in the basin and on the water outflowing at the Strait. Indeed the CNRM-RCSM4-SN presents a stronger net heat loss (Table 2) due to a stronger latent heat loss (Sevault et al. 2014). Hence hydrographic changes induced by changes in the atmospheric conditions may impact the exchange at the Strait. It is interesting to further investigate these changes in particular the water masses involved and the consequences on the thermohaline circulation.

Most models agree with observations on the Mediterranean warming. However, the model spread is large and the rates are higher than in the observations, especially for the 


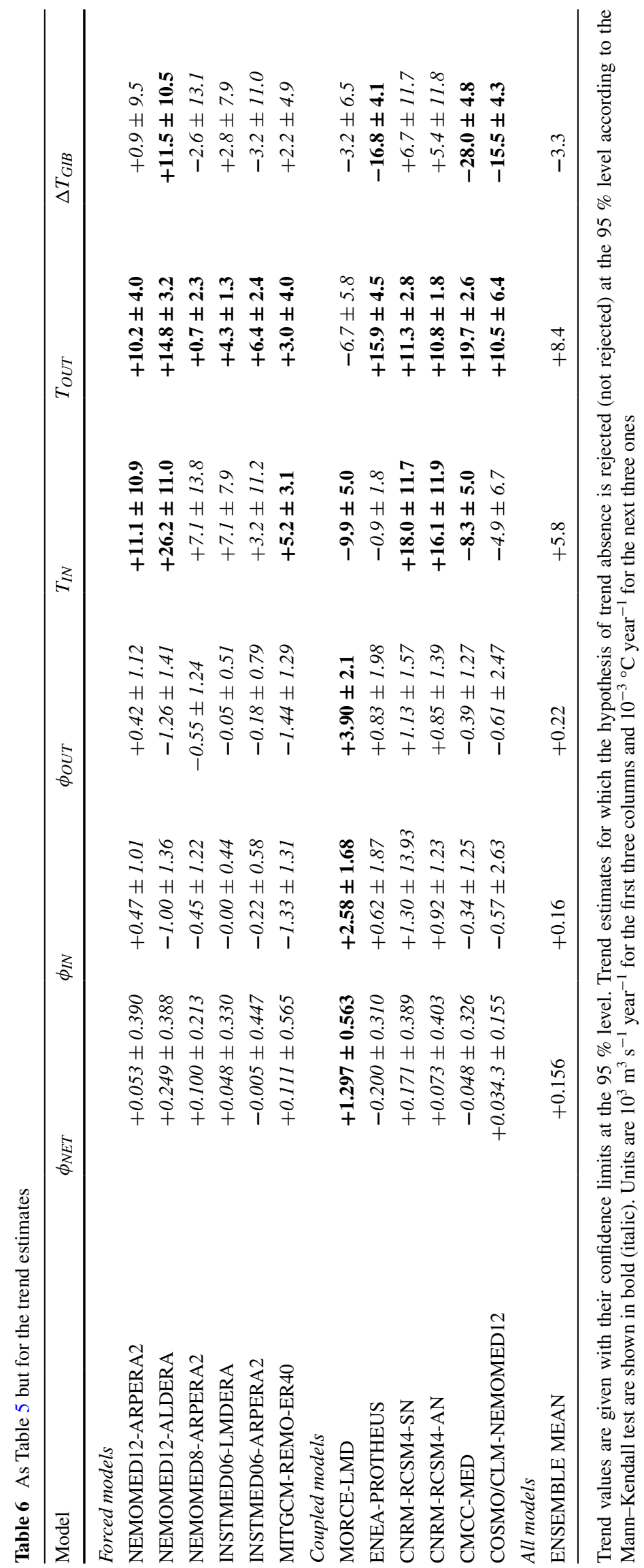


coupled models. The trend in the Mediterranean average temperature results from an imbalance between the different terms in (1), and especially between the net heat fluxes at the sea surface and at the Strait of Gibraltar. The model ensemble spread in the mean value of those two components, in particular in the net heat flux at the sea surface, explains the different warming rates among models (see Table 2). Unfortunately, there are no independent observational data sets that could be used to constrain with enough accuracy neither the mean heat loss at the surface nor the mean heat gain through the Strait of Gibraltar (MedMAHB report 2015, http://marine-climate.uib.es/medworkshop. html).

The present study showed differences between the forced and coupled model simulations, in particular the larger spread in the coupled ones. The larger spread in the mean net heat flux at sea surface in coupled models (range from -3.5 to $+2.2 \mathrm{Wm}^{-2}$ while -4.8 to $-2.9 \mathrm{Wm}^{-2}$ in the forced models), and the lower correlations of the average temperature with observations also in coupled models (Sect. 3.1) may be related, at least partly, to the atmospheric internal variability generated inside the domain of the regional models (e.g. Laprise et al. 2012; Herrmann et al. 2011). The trace of the internal variability remains even for averages over a long period (Laprise et al. 2012; de Elía et al. 2007). Hence, the atmospheric patterns simulated by the regional models may differ from the patterns of the driving analyses. In the present simulations, despite the high intermodel correlation values shown above, some intermodel variability exists in the net heat flux at the sea surface series (std of $2.7 \mathrm{Wm}^{-2}$ ) and is almost the same for coupled and forced models. It is suggested that part of it is attributed to the internal variability generated inside the model domain. In the coupled models such internal variability is transmitted to (and feedbacks with) the ocean component through the two-way fluxes at sea-atmosphere interface. In the forced models the ocean component is constrained by the relaxation to the observed or climatic sea surface temperatures (see Table 1) damping the effect of the internal variability. This gives an explanation to the lower correlations of the heat content rate with observations in the coupled models than in the forced ones.

The initial conditions and spin-up may have an effect on the average temperature mean value and evolution. Simulations showing higher mean temperature value (e.g. CMCCMED, ENEA-PROTHEUS, CNRM-RCSM4-AN) also have higher temperature value at the start of the simulation. Overall, the correlation between the temperature bias relative to observations at the start of the simulation and the mean temperature during the simulation is 0.78 , significant at the $99 \%$ level. This shows the crucial role of the starting state especially for coupled models (e.g. CMCC-MED). The impact of the initial conditions and spin-up on the average temperature interannual variability is less important as temperature variations are driven mainly by the heat fluxes at the sea surface (see Fig. 2). We also mention that the effect of the spin-up duration is difficult to investigate as several simulations use nearly the same length whereas no spin-up is used in other simulations.

Different approaches are used in the models shown in this study to simulate the Atlantic zone (see Table 1). In particular the internannual variability of the temperature and salinity are considered in some models whereas others use climatological values. The sea level is also used with climatological or interannually varying values but in addition some models consider open boundary conditions permitting explicit mass exchange (INSTMED06) or a mass exchange deduced by relaxing the sea level towards an observational data set (e.g. NEMOMED12). Attempts were made to investigate the impacts of the varying Atlantic conditions but due to the limitation in the number of cases no conclusive results were reached.

The models used have different resolutions both in the horizontal and vertical coordinates. In addition most models use spatially varying coordinates with increased resolution when approaching the Strait of Gibraltar. The width of the strait of Gibraltar is represented by two or three grid points in the different models. The INSTMED06 model which has a comparatively coarse resolution in the Mediterranean basin uses three grid points. Hence it is not straightforward to investigate the impacts of the resolution on the heat budget of the Mediterranean Sea. On the other hand there is some evidence that models with a deeper Strait of Gibraltar simulate stronger water and heat exchange. Again, although this is needed to be confirmed as it is based on only four different values of the strait depth (see Table 1), it highlights the importance of reproducing, as accurately as possible, the strait geometry in the models, in particular its depth.

\section{Conclusions}

The heat budget components of the Mediterranean Sea are studied based on a set of numerical simulations performed using the RCSMs which include both forced and coupled models. The first ones are Mediterranean Sea models forced by downscaled versions of the ERA40/ERA-Interim reanalyses. For the coupled ones the atmospheric components are driven outside the Mediterranean domain by the ERA-Interim reanalysis meanwhile they are free to evolve inside the domain. The study focuses on mean values and trends of the heat budget components for the 1980-2010 period (31 years). Model results are compared to available observations and to previous simulations.

The different models simulate similar evolutions of the Mediterranean Sea average temperature in agreement with 
observations. Major climate events, as the cooling after 1980 and the sudden warming in 1990, are well reproduced by the models. This consistency is attributed to the use of the same atmospheric reanalyses (ERA40/ERA-Interim) in the atmospheric components of the RCSMs used. The heat content rate presents a similarity among models and is highly related to the surface heat fluxes. On the other hand, the heat fluxes through the Strait of Gibraltar show a large intermodel spread and little impact on the heat content rate variability. In addition the initial conditions determine the mean value of the average temperature and have an impact on the temperature trends. However it does not seem to affect the interannual variability.

Average temperature trends are positive and significant in most models. They are larger than the trends computed from observational products. Higher temperature trends and lower surface heat losses are simulated by the coupled models compared to the forced ones. At the opposite, the mean values of the net heat flux at the Strait of Gibraltar are nearly the same in the forced and coupled models. Hence the higher temperature trends in the coupled models are attributed to the larger heat budget imbalance simulated in those models, resulting mainly from their lower surface heat loss. The resemblance between the simulated and observed heat content rates is stronger in the forced models than in the coupled ones. This is attributed to the effect of the sea surface temperature relaxation in the forced models, which reduces the impact of the internal variability generated inside the domain and brings the simulated temperatures closer to the observed ones.

At the Strait of Gibraltar, all models simulate a positive net heat gain with values ranging between +1.5 and $+6.8 \mathrm{Wm}^{-2}$ and a mean of $4.9 \mathrm{Wm}^{-2}$. The intermodel spread is due to the different values in the temperature difference between inflowing and outflowing waters at the Strait, in the exchange transports and in the net water flux. Unfortunately, the observational data sets are not accurate enough to constrain the mean values of the net heat fluxes at the sea surface and at the Strait of Gibraltar. It is also worth mentioning that the net water flux at the Strait of Gibraltar is similar for most models with intermodel spread relatively small $(0.04 \mathrm{~Sv})$ in both forced and coupled models. This is expected for the forced models that are forced by the same atmospheric water fluxes at the sea surface but was not obvious for the coupled models. Further studies are needed to better understand the water cycle simulated by the different models and its impact on the heat budget of the Mediterranean Sea.

Large differences between models are found in the temperatures of the inflowing and outflowing waters, which reflect differences in the way the Atlantic Ocean is considered and differences in the initial conditions and spinup periods. However, due to the limitation in the number of cases no conclusive results were reached. The temperature of the outflowing water shows positive and significant trends. The trends are higher in the coupled models than in the forced ones. It is assumed that the Mediterranean Sea warming, found in most models and in particular in the coupled ones, induces changes in the hydrographic conditions that impact the Strait of Gibraltar.

Acknowledgments This work is part of the Med-CORDEX initiative (www.medcordex.eu) supported by the HyMeX programme (www. hymex.org). Naveed Akhtar acknowledges the research program MiKlip funded by the German ministry of education and research (BMBF). G. Jordà acknowledges a Ramón y Cajal contracts funded by the Spanish Ministry of Economy and the Regional Government of the Balearic Islands. Special thanks to two anonymous reviewers for their constructive comments, which helped us to significantly improve the manuscript.

\section{Appendix: Description of models and simulations used}

The NEMOMED12-ARPERA2 (Beuvier et al. 2012) and NEMOMED12-ALDERA (Hamon et al. 2015) simulations are based on the NEMO platform ocean model (Madec 2008). NEMOMED12 has a resolution varying from 6.5 to $8 \mathrm{~km}\left(1 / 14\right.$ to $\left.1 / 18^{\circ}\right)$ in latitude and 5.5 to $7.5 \mathrm{~km}$ in longitude. The grid extends westward to cover the near Atlantic Ocean. The model has 50 (resp. 75) vertical levels on the $\mathrm{z}$ coordinate for the NEMOEMD12-ARPERA2 (resp. NEMOMED12-ALDERA) simulation. The first simulation, NEMOMED12-ARPERA2, uses as atmospheric forcing the ARPERA2 data set, a dynamically downscaling of ECMWF reanalysis ERA40 using the ARPEGE-Climate model (Herrmann and Somot 2008; Herrmann et al. 2010; Beuvier et al. 2010). Inside the Mediterranean domain a spectral nudging of the large scales is applied whereas small scales are free to develop. For the oceanic simulation, the relaxation approach (e.g. Haney 1971; Barnier et al. 1995) brings the sea surface temperature (SST) close to the ERA40 values whereas no correction is added to salinity. The initial state is MEDATLAS-1960 where a mean monthly cycle of the MEDATLAS climatology (MEDAR/ MEDATLAS Group 2002) combined to the 10-year filtered interannual fields from Rixen et al. (2005) representative of the 1955-1965 period are used. Temperature and salinity in the Atlantic area are relaxed towards interannual values from the ENSEMBLES oceanic reanalysis (Daget et al. 2009). Sea level is relaxed towards perpetual values, except between 2002 and 2008 where it is relaxed towards the GLORYS1V1 oceanic reanalysis (Ferry et al. 2010). The simulation covers the period 1959-2013 (55 years). The second simulation, NEMOMED12-ALDERA uses as atmospheric forcing the ALDERA dataset, a dynamical downscaling of the ERA-Interim atmospheric reanalysis 
from the ECMWF with the ALADIN-Climate regional climate model (Herrmann et al. 2011; Hamon et al. 2015). In this simulation, SST is relaxed towards ERA-Interim values and a 2D monthly freshwater correction is added to the atmospheric water fluxes. The initial state is MEDATLAS-1979 where a mean monthly cycle of the MEDATLAS climatology combined to the 3-year filtered interannual fields from Rixen et al. (2005) are used. Temperature and salinity in the Atlantic area are relaxed towards interannual values from the ORAS- 4 oceanic reanalysis (Balmaseda et al. 2013). Sea level is relaxed towards interannual values from the same ORAS-4 oceanic reanalysis. This second simulation covers the period 1980-2012 (33 years).

The NEMOMED8-ARPERA2 (Beuvier et al. 2010; Herrmann et al. 2010) simulation uses the NEMOMED8 model which covers the Mediterranean Sea and a buffer zone in the near Atlantic Ocean. The horizontal resolution is nearly $1 / 8^{\circ}$ which corresponds to grid sizes between 9 and $12 \mathrm{~km}$ with increased resolution (two grid points) at the Gibraltar Strait. The model has 43 z-coordinate levels. The atmospheric forcing also uses the downscaled ERA40 reanalyses using the ARPEGE-Climate model. SST is relaxed to the ERA40 values and monthly flux correction is applied for salinity. In the Atlantic zone, varying temperature and salinity from analysed fields are used and sea level is set to a value equilibrating the net evaporation at the basin sea surface. The initial conditions use the MEDTALAS data set. The simulation is started after a 15 -year spin-up.

The INSTMED06 model (Alioua and Harzallah 2008) is based on the Princeton Ocean Model (Mellor and Yamada 1982; Mellor and Blumberg 1985). The same configuration was used to study the long-term changes in the Mediterranean Sea (Gualdi et al. 2013b) and to investigate the impact of tide on the thermohaline circulation of the Mediterranean basin (Harzallah et al. 2014). The model grid is curvilinear and extends westward over the Atlantic Ocean to nearly $7.88^{\circ} \mathrm{W}$. The vertical resolution uses $27 \sigma$ layers. The average horizontal resolution is $1 / 6^{\circ}$ but it is strongly increased at the Strait of Gibraltar where the minimum width is represented by three grid points $(\sim 4 \mathrm{~km})$. The strait minimum depth is $247 \mathrm{~m}$. The water temperature and salinity at the sea surface and in the Atlantic buffer zone are relaxed to the MODB climatology (Brasseur et al. 1996; Brankart and Brasseur 1998). The same climatology was used as an initial state in a 30-year model spin-up. Radiation conditions with dynamically open boundaries are used in the Atlantic limit. Hence no equilibrium condition is applied. Two simulations were performed using this model. For the first one the atmospheric forcing used are the ERA40/ERA-Interim reanalyses for the period 1958-2007 downscaled to $30 \mathrm{~km}$ resolution by the LMDzMed (Li 1999; Hourdin et al. 2006) and zoomed over the Mediterranean Sea (L'Heveder et al.
2013; Rojas et al. 2013). The simulation performed with this forcing is labelled INSTMED06-LMDERA. The second simulation uses a similar downscaling but again with the Arpège-Climate model (hearafter, INSTMED06-ARPERA2). To correct for ERA40/ERA-Interim bias effects, constant heat flux values (values obtained assuming no temperature trend during the decade 1959-1967) are added and are shown to be sufficient to remove bias-related drifts. In addition the added heat loss is almost completely recovered by surface relaxation that restores the net heat flux at the sea surface to more realistic values. Details of such a correction are shown in Harzallah et al. (2014).

MITGCM-REMO is a version of the MITgcm ocean model (Marshall et al. 1997) adapted for the Mediterranean basin. The model is used in its hydrostatic, implicit free-surface, partial step topography formulation. It has been implemented at a horizontal resolution of $1 / 12^{\circ}$ with 72 vertical unevenly spaced z-levels. MITGCM-REMO is forced at the surface using six hourly heat and salt fluxes derived by a dynamical downscaling of the ERA40 reanalysis performed with the regional atmospheric model REMO. The simulation covers the period 1958-2004; it is initialized using the MEDATLAS monthly climatology data for January. The run has been performed using a relaxation to daily SST and monthly SSS climatological values, with relaxation times of 8 and 15 days respectively. A 3D relaxation of temperature and salinity toward climatological monthly Levitus data is applied at the Atlantic boundary.

MORCE (MOdel of the Regional Coupled Earth System) is a regional coupled modelling system (Drobinski et al. 2012). The atmospheric component is the non-hydrostatic WRF (Weather Research and Forecasting) model developed at NCAR. Its ocean component is NEMOMED12 with a $1 / 12^{\circ}$ horizontal resolution $(\sim 7 \mathrm{~km})$. The MORCE-LMD model was developed at the Laboratoire de Météorologie Dynamique for the Mediterranean basin. The MORCE-LMD simulations cover the 19892012 period. The atmospheric component uses the ERAInterim for initial and lateral boundary conditions. The ocean component uses as initial conditions, the MODB4 climatology (Brankart and Brasseur 1998) and the Levitus climatology (Levitus et al. 2005) in the buffer zone. In this area the sea surface elevation is set to monthly observational products. Reynolds SST are used as background during the simulation.

ENEA-PROTHEUS is an atmosphere-ocean coupled climate model for the Euro-Mediterranean region (Artale et al. 2010). The atmospheric component is the regional climate model RegCM3 and the ocean one is a regional configuration of the MITgcm model (Marshall et al. 1997). The ocean model has a horizontal resolution of $1 / 8 \times 1 / 8^{\circ}$ and uses 42 vertical $z$-levels. The initial conditions for the ocean are derived from a stand-alone run performed using 
3D relaxation of temperature and salinity towards MEDATLAS climatology, with a relaxation coefficient of 5 days. At the surface, the model was forced perpetually by heat and water fluxes derived from year 1958 of the ERA40 data set. The two-way exchange through the Strait of Gibraltar is achieved by means of 3D relaxation of salinity and temperature toward the climatological monthly Levitus (1982) data.

The atmospheric component of the coupled model CNRM-RCSM4 is ALADIN-Climate (Radu et al. 2008; Colin et al. 2010; Herrmann et al. 2011). The horizontal resolution is $50 \mathrm{~km}$ with $128 \mathrm{X} 90$ grid points. It includes land surface and rivers models. The simulation uses the ERA-Interim for atmospheric lateral boundary conditions. The atmospheric model is coupled to the NEMOMED8 Mediterranean Sea model presented above. In the Atlantic buffer zone a 3D damping is performed to varying temperature and salinity values. The relaxation is also applied to the sea level in the Atlantic zone. Outside the Mediterranean domain the ERA-Interim SSTs are used. The model is run for the period 1980-2012. This simulation is labelled CNRM-RCSM4-AN. A second simulation (CNRM-RCSM4-SN) is performed using the same model and configuration but applying a spectral nudging of the large scales inside the Mediterranean.

The CMCC model (Cavicchia et al. 2015) is based on the coupling between the COSMO-CLM atmospheric limited area model and the NEMO-MFSocean model. The atmospheric component COSMO-CLM is implemented with a spatial resolution of about $0.44^{\circ}$ and 40 vertical levels. The ocean component NEMO-MFS is a regional configuration of NEMO model with a $1 / 16^{\circ}$ horizontal resolution and $71 \mathrm{z}$-vertical levels. The spatial domain covers the Mediterranean region including an Atlantic box. In the present simulation, the atmospheric model is forced by the ERA-Interim lateral boundary conditions for the period 1980-2011. The ocean model uses climatological conditions on the open Atlantic boundary. A 25-year spin-up of the coupled system is performed before starting the integration, while initial conditions are derived from the MEDATLAS climatology.

The COSMO/CLM-NEMOMED12 is a regional coupled ocean-atmosphere model (Akhtar et al. 2014). Its atmospheric component, COSMO/CLM (Kothe et al. 2014) covers the Med-CORDEX domain (Ruti et al. 2015). The horizontal resolution for the atmospheric component is $0.44^{\circ}(\sim 50 \mathrm{~km} ; 114 \times 79$ grid points $)$. It uses 32 vertical $\sigma$ levels. The ocean component is NEMOMED12 (presented above). The simulations cover the period 1980-2012 (32 years) and use the ERA-Interim fields as atmospheric lateral boundary conditions.

The above described twelve simulations use five ocean models and seven atmospheric ones. For example the NEMOMED12 Mediterranean Sea model is used in two forced simulations, NEMOMED12-ARPERA2 and NEMOMED12-ALDERA, and in two coupled ones, MORCE-LMD-ERAINT and COSMO/CLMNEMOMED12. Therefore the model outputs cannot be considered completely statistically independent. Nevertheless the forced and coupled subsets contain each a sufficient number of simulations (six) that permit to investigate how the ocean-atmosphere coupling modifies the skills of the models. In addition the entire set can be considered sufficiently large to enable performing basic statistics.

Open Access This article is distributed under the terms of the Creative Commons Attribution 4.0 International License (http://creativecommons.org/licenses/by/4.0/), which permits unrestricted use, distribution, and reproduction in any medium, provided you give appropriate credit to the original author(s) and the source, provide a link to the Creative Commons license, and indicate if changes were made.

\section{References}

Akhtar N, Brauch J, Dobler A, Berenger K, Ahrens B (2014) Medicanes in an ocean-atmosphere coupled regional climate model. Nat Hazards Earth Syst Sci 14:2189-2201

Alioua M, Harzallah A (2008) Imbrication d'un modèle de circulation des eaux près des côtes tunisiennes dans un modèle de circulation de la mer Méditerranée [Nesting of a water circulation model along the Tunisia coasts in a Mediterranean Sea model]. Bull Inst Nat Sci Technol Mer de Salammbô 35:169-176

Artale V, Calmanti S, Carillo A, Dell'Aquila A, Herrmann M, Pisacane G, Ruti PM, Sannino G, Struglia MV, Giorgi F, Xunqiang B, Pal JS, Rauscher S (2010) An atmosphere-ocean regional climate model for the Mediterranean area: assessment of a present climate simulation. Clim Dyn 35:721-740

Astraldi M, Balopoulos S, Candela J, Font J, Gacic M, Gasparini GP, Manca B, Theocharis A, Tintore J (1999) The role of straits and channels in understanding the characteristics of Mediterranean circulation. Prog Oceanogr 44(1-3):65-108

Balmaseda MA, Mogensen K, Weaver AT (2013) Evaluation of the ECMWF ocean reanalysis system ORAS4. Q J R Meteorol Soc 139:1132-1161. doi:10.1002/qj.2063 - See more at:https://climatedataguide.ucar.edu/climate-data/oras4-ecmwf-ocean-reanalysis-and-derived-ocean-heat-content\#sthash.jk3UcFWF.dpuf

Barnier B, Siefridt L, Marchesiello P (1995) Thermal forcing for a global ocean circulation model using a 3-year climatology of ECMWF analyses. J Mar Syst 6(4):363-380

Baschek B, Send U, Lafuente JG, Candela J (2001) Transport estimates in the Strait of Gibraltar with a tidal inverse model. J Geophys Res 106(C12):31033-31044

Bethoux JP (1979) Budgets of the Mediterranean Sea. Their dependence on the local climate and on the characteristics of the Atlantic waters. Oceanol Acta 2:157-163

Bethoux JP, Gentili B (1996) The Mediterranean Sea, coastal and deep-sea signatures of climatic. J Mar Syst 7:383-394

Bethoux JP, Gentili B (1999) Functioning of the Mediterranean Sea: past and present changes. J Mar Syst 20:33-47

Bethoux JP, Gentili B, Tailliez D (1998) Warming and freshwater budget change in the Mediterranean since the 1940s, their possible relation to the greenhouse effect. Geophys Res Lett 25:1023-1026

Beuvier J, Sevault F, Herrmann M, Kontoyiannis H, Ludwig W, Rixen M, Stanev E, Béranger K, Somot S (2010) Modeling the 
Mediterranean Sea interannual variability during 1961-2000: focus on the Eastern Mediterranean Transient. J Geophys Res 115:C08017. doi:10.1029/2009JC005950

Beuvier J, Béranger K, Lebeaupin Brossier C, Somot S, Sevault F, Drillet Y, Bourdallé-Badie R, Ferry N, Lyard F (2012) Spreading of the Western Mediterranean deep water after winter 2005: time scales and deep cyclone transport. J Geophys Res 117:C07022. doi:10.1029/2011JC007679

Brankart JM, Brasseur P (1998) The general circulation in the Mediterranean Sea: a climatological approach. J Mar Syst 18:41-70

Brankart JM, Pinardi N (2001) Abrupt cooling of the Mediterranean Levantine intermediate water at the beginning of the 1980s: observational evidence and model simulation. J Phys Oceanogr 31:2307-2320. doi:10.1175/1520-0485(2001)031<2307:ACOT ML $>2.0 . \mathrm{CO} ; 2$

Brasseur P, Brankart JM, Schoenauen R, Bechers JM (1996) Seasonal temperature and salinity fields in the Mediterranean Sea: climatological analyses of an historical data set. Deep Sea Res 43:159-192

Bryden HL, Candela J, Kinder TH (1994) Exchange through the strait of Gibraltar. Prog Oceanogr 33(3):201-248

Cavicchia L, Gualdi S, Sanna A, Oddo P (2015) The regional oceanatmosphere coupled model COSMO-NEMO_MFS." CMCC Research Paper RP0254

Colin J, Déqué M, Radu R, Somot S (2010) Sensitivity study of heavy precipitation in limited area model climate simulations: influence of the size of the domain and the use of the spectral nudging technique. Tellus A 62:591-604

Criado-Aldeanueva F, Javier Soto-Navarro FJ, García-Lafuente J (2012) Seasonal and interannual variability of surface heat and freshwater fluxes in the Mediterranean Sea: budgets and exchange through the Strait of Gibraltar. Int J Climatol 32(2):286-302

Daget N, Weaver AT, Balmaseda MA (2009) Ensemble estimation of backgrounderror variances in a three-dimensional variational data assimilation system for the global ocean. Q J R Meteorol Soc 135:1071-1094

de Elía R, Caya D, Frigon A, Côté H, Giguère M, Paquin D, Biner S, Harvey R, Plummer D (2007) Evaluation of uncertainties in the CRCM-simulated North American climate: nesting-related issues. Clim Dyn 30(2):113-132

Dee DP, Uppala SM, Simmons AJ, Berrisford P, Poli P et al (2011) The ERA-Interim reanalysis: configuration and performance of the data assimilation system. Q J R Meteorol Soc 137:553-597. doi:10.1002/qj828

Drobinski P, Anav A, Lebeaupin Brossier C, Samson G, Stéfanon M, Bastin S, Baklouti M, Béranger K, Beuvier J, Bourdallé-Badie R, Coquart L, D'Andrea F, De Noblet-Ducoudré N, Diaz F, Dutay JC, Ethe C, Foujols MA, Khvorostyanov D, Madec G, Mancip M, Masson S, Menut L, Palmieri J, Polcher J, Turquety S, Valcke S, Viovy N (2012) Modelling the regional coupled earth system (MORCE): application to process and climate studies in vulnerable regions. Environ Modell Softw 35:1-18

Drobinski P, Ducrocq V, Alpert P, Anagnostou E, Béranger K, Borga M, Braud I, Chanzy A, Davolio S, Delrieu G, Estournel C, Filali Boubrahmi N, Font J, Grubišić V, S, Homar V, Ivančan-Picek B, Kottmeier C, Kotroni V, Lagouvardos K, Lionello P, Llasat MC, Ludwig W, Lutoff C, Mariotti A, Richard E, Romero R, Rotunno R, Roussot O, Ruin I, Somot S, Taupier-Letage I, Tintore J, Uijlenhoet R, Wernli H (2014) HyMeX: a 10-year multidisciplinary program on the Mediterranean water cycle. Bull Am Meteorol Soc 95:1063-1082. doi:10.1175/BAMS-D-12-00242.1

Dubois C, Somot S, Calmanti S, Carillo A, Déqué M, Dell'Aquilla A, Elizalde A, Gualdi S, Jacob D, L'Hévéder B, Li L, Oddo P, Sannino G, Scoccimarro E, Sevault F (2012) Future projections of the surface heat and water budgets of the Mediterranean Sea in an ensemble of coupled atmosphere-ocean regional climate models. Clim Dyn 39:1859-1884. doi:10.1007/s00382-011-1261-4

Fenoglio-Marc L, Mariotti A, Sannino G, Meyssignac B, Carillo A, Struglia MV, Rixen M (2013) Decadal variability of net water flux at the Mediterranean Sea Gibraltar Strait. Glob Planet Change 100:1-10

Ferry N, Parent L, Garric G, Barnier B, Jourdain NC (2010) Mercator global Eddy permitting ocean reanalysis GLORYS1V1: description and results. Mercat Ocean Q Newsl 36:15-27

Garrett C, Outerbridge R, Thomson K (1993) Interannual variability in Mediterranean heat and buoyancy fluxes. J Clim 6:900-910

Gomis D, Tsimplis MN, Martin-Miguez B, Ratsimandresy AW, Garcia-Lafuente J, Josey SA (2006) Mediterranean Sea level and barotropic flow through the Strait of Gibraltar for the period 1958-2001 and reconstructed since 1659. J Geophys Res 111:C11005. doi:10.1029/2005JC003186

Good SA, Martin MJ, Rayner NA (2013) EN4: quality controlled ocean temperature and salinity profiles and monthly objective analyses with uncertainty estimates. J Geophys Res Oceans 118:6704-6716. doi:10.1002/2013JC009067

Gualdi S, Somot S, Li L, Artale V, Adani M, Bellucci A, Braun A, Calmanti S, Carillo A, Dell'Aquila A, Déqué M, Dubois C, Elizalde A, Harzallah A, Jacob D, L'Hévéder B, May W, Oddo P, Ruti P, Sanna A, Sannino G, Scoccimarro E, Sevault F, Navarra A (2013a) The CIRCE simulations: regional climate change projections with realistic representation of the Mediterranean Sea. Bull Am Meteorol Soc 94:65-81

Gualdi S, Somot S, May W, Castellari S, Déqué M, Adani M, Artale V, Bellucci A, Breitgand AW, Carillo A, Cornes R, Dell'Aquila A, Dubois C, Efthymiadis D, Elizalde A, Gimeno L, Goodess CM, Harzallah A, Krichak SO, Kuglitsch FG, Leckebusch GC, L'Heveder B, Li L, Lionello P, Luterbacher J, Mariotti A, Navarra A, Nieto R, Nissen KM, Oddo P, Ruti P, Sanna A, Sannino G, Scoccimarro E, Sevault F, Struglia MV, Toreti A, Ulbrich U, Xoplaki E (2013b) Future climate projections. In: Navarra A, Tubiana L (eds) Regional assessment of climate change in the Mediterranean, vol 1. Springer, Dordrecht, pp 53-118

Hamon M, Beuvier J, Somot S, Lellouche JM, Greiner E, Jordà G, Bouin MN, Arsouze T, Béranger K, Sevault F, Dubois C, Drevillon M, Drillet Y (2015) Design and validation of MEDRYS, a Mediterranean Sea reanalysis over 1992-2013. Ocean Sci Discuss 12:1815-1867. doi:10.5194/osd-12-1815-2015

Haney RL (1971) Surface thermal boundary condition for ocean circulation models. J Phys Oceanogr 1:145-167

Harzallah A (1990) Etude aérologique et océanique de l'hydrologie du bassin méditerranéen. 'Aerological and oceanic study of the hydrology of the Mediterranean basin'. PhD thesis, Laboratoire de Météorlogie Dynamique, Ecole Polytechnqiues, Palaiseau, France. Available at Univeristé Paris 6, 4, place Jussieu, 75005, Paris, France

Harzallah A, Crépon M, Cadet DL (1993) Possible forcing effects of net evaporation, atmospheric pressure, and transients on water transports in the Mediterranean Sea. J Jeophys Res 98(C7):12341-12350. doi:10.1029/93JC00376

Harzallah A, Alioua M, Li L (2014) Mass exchange at the Strait of Gibraltar in response to tidal and lower frequency forcing as simulated by a Mediterranean Sea model. Tellus A 66:23871. doi:10.3402/tellusa.v66.23871

Herrmann MJ, Somot S (2008) Relevance of ERA40 dynamical downscaling for modeling deep convection in the Mediterranean Sea. Geophys Res Lett 35:L04607. doi:10.1029/2007GL032442

Herrmann M, Sevault F, Beuvier J, Somot S (2010) What induced the exceptional 2005 convection event in the Northwestern Mediterranean basin? Answers from a modeling study. J Geophys Res 115:C12051. doi:10.1029/2010JC006162 
Herrmann M, Somot S, Calmanti S, Dubois C, Sevault F (2011) Representation of spatial and temporal variability of daily wind speed and of intense wind events over the Mediterranean Sea using dynamical downscaling: impact of the regional climate model configuration. Nat Hazards Earth Syst Sci 11:1983-2001

Hourdin F, Musat I, Bony Braconnot P, Codron F, Dufresne JL, Fairhead L, Filiberti MA, Friedlingstein P, Grandpeix JY, Krinner G, Levan P, Li ZX, Lott F (2006) The LMDZ4 general circulation model: climate performance and sensitivity to parametrized physics with emphasis on tropical convection. Clim Dyn 27:787-813

Ingleby B, Huddleston M (2007) Quality control of ocean temperature and salinity profiles-historical and real-time data. J Mar Syst 65:158175. doi:10.1016/j.jmarsys.2005.11.019

Jordà G, Sánchez-Román A, Gomis D (2016) Reconstruction of transports through the Strait of Gibraltar from limited observations. Clim Dyn. doi:10.1007/s00382-016-3113-8

Josey SA, Kent EC, Taylor PK (1999) New insights into the ocean heat budget closure problem from analysis of the SOC air-sea flux climatology. J Clim 12:2856-2880

Kendall MG (1975) Rank correlation methods. Griffin, London

Kothe S, Panitz HJ, Ahrens B (2014) Analysis of the radiation budget in regional climate simulations with COSMO-CLM for Africa. Meteorol Z 23(2):123-141. doi:10.1127/0941-2948/2014/0527

L'Heveder B, Li L, Sevault F, Somot S (2013) Interannual variability of deep convection in the Northwestern Mediterranean simulated with a coupled AORCM. Clim Dyn 41:937-960. doi:10.1007/ s00382-012-1527-5

Laprise R, Kornic D, Rapaić M, Šeparović L, Leduc M, Nikiema O, Di Luca A, Diaconescu E, Alexandru A, Lucas-Picher P, de Elía R, Caya R, Biner S (2012) Considérations of domain size and large-scale driving for nested regional climate models: impact on internal variability and skill at developing small-scale details. In: Berger A et al (eds) Proceedings of the Milutin Milankovitch Anniversary Symposium. Climate change. doi: 10.1007/978-3-7091-0973-1_14

Levitus S (1982) Climatological Atlas of the World Ocean, NOAA/ERL GFDL Professional Paper 13. Princeton, NJ, p 173

Levitus S, Antonov J, Boyer T (2005) Warming of the world ocean, 1955-2003. Geophys Res Lett 32:L02604. doi:10.1029/200 4GL021592

Li ZX (1999) Ensemble atmospheric GCM simulation of climate interannual variability from 1979 to 1994 . J Clim 12:986-1001

Llasses J, Jordà G, Gomis D, Adloff F, Macías D, Harzallah, A, Arsouze T, Akthar N, Li L, Elizalde A, Sannino G (2016) Heat and salt redistribution within the Mediterranean Sea in the Med-CORDEX model ensemble. Clim Dyn 1-25. doi:10.1007/ s00382-016-3242-0

MacDonald AM, Candela J, Bryden HL (1994) An estimate of the net heat transport through the Strait of Gibraltar. In: LaViolette PE (ed) Seasonal and interannual variability of the Western Mediterranean Sea. Coastal Estuarine Stud. AGU, Washington DC, pp $13-32$

Madec G (2008) NEMO ocean engine, Note Pôle Model. 27, Inst. Pierre-Simon Laplace des Sci. de l'Environ., Paris, France

Manca B, Burca M, Giorgetti A, Coatanoan C, Garcia MJ, Iona A (2004) Physical and biochemical averaged vertical profiles in the Mediterranean regions: an important tool to trace the climatology of water masses and to validate incoming data from operational oceanography. J Mar Syst 48(1-4):83-116

Mann HB (1945) Nonparametric tests against trend. Econometrica $13: 245-259$

Mariotti A (2010) Recent changes in the Mediterranean water cycle: A pathway toward long-term regional hydroclimatic change? J Clim 23(6):1513-1525. doi:10.1175/2009JCLI3251.11IF(2009) $=3.3632 \mathrm{CIT}=32$
Mariotti A, Struglia MV, Zeng N, Lau KM (2002) The hydrological cycle in the Mediterranean region and implications for the water budget of the Mediterranean Sea. J Clim 15:1674-1690

Marshall J, Adcroft A, Hill C, Perelman L, Heisey C (1997) A finite-volume, incompressible Navier-Stokes model for studies of the ocean on parallel computers. J Geophys Res 102(C3):5753-5766

MEDAR/MEDATLAS Group (2002) MEDATLAS/2002 database. Mediterranean and Black Sea database of temperature salinity and bio-chemical parameters. Climatological Atlas. Institut Français de Recherche pour L'Exploitation de la Mer, (IFREMER) Edition and Instituto Nazionale di Oceanografia e di Geofisica Sperimentale (OGS), 4 CD-ROM

Mellor GL, Blumberg AF (1985) Modelling vertical and horizontal diffusivities with the sigma coordinate system. Mon Weather Rev 113:1279-1383

Mellor GL, Yamada T (1982) Development of turbulent closure model for geophysical fluid problems. Rev Geophys 20:851-875

Millot C, Candela J, Fuda JL, Tber Y (2006) Large warming and salinification of the Mediterranean outflow due to changes in its composition. Deep-Sea Res I 53:656-666

Pettenuzzo D, Large WG, Pinardi N (2010) On the corrections of ERA-40 surface flux products consistent with the Mediterranean heat and water budgets an the connection between basin surface total heat flux and NAO. J Geophys Res 115:C06022. doi:10.10 29/2009JC005631

Radu R, Déqué M, Somot S (2008) Spectral nudging in a spectral regional climate model. Tellus A 60:898-910

Rixen M, Beckers JM, Brankart JM, Brasseur P (2001) A numerically efficient data analysis method with error map generation. Ocean Model 2:45-60

Rixen M, Beckers JM, Levitus S, Antonov J, Boyer T, Maillard C, Fichaut M, Baloupos E, Iona S, Dooley H, Garcia MJ, Manca B, Giorgetti A, Manzella G, Mikhailov N, Pinardi N, Zavatarelli M (2005) The Western Mediterranean deep water: a proxy for climate change. Geophys Res Lett 32:L12608. doi:10.1029/200 5GL022702(2949-2952)

Rojas M, Li LZ, Kanakidou M, Hatzianastassiou N, Seze G, Le TH (2013) Winter weather regimes over the mediterranean region: their role for the regional climate and projected changes in the twenty-first century. Clim Dyn 41:551-571. doi:10.1007/ s00382-013-1823-8

Ruti PM, Somot S, Giorgi F, Dubois C, Flaounas E, Obermann A, Dell'Aquila A, Pisacane G, Harzallah A, Lombardi E, Ahrens B, Akhtar N, Alias A, Arsouze T, Aznar R, Bastin S, Bartholy J, Béranger K, Beuvier J, Bouffies-Cloché S, Brauch J, Cabos W, Calmanti S, Calvet J-C, Carillo A, Conte D, Coppola E, Djurdjevic V, Drobinski P, Elizalde-Arellano A, Gaertner M, Galàn $\mathrm{P}$, Gallardo $\mathrm{C}$, Gualdi $\mathrm{S}$, Goncalves $\mathrm{M}$, Jorba $\mathrm{O}$, Jordà $\mathrm{G}$, L'Heveder B, Lebeaupin-Brossier C, Li L, Liguori G, Lionello P, Maciàs D, Nabat P, Onol B, Raikovic B, Ramage K, Sevault F, Sannino G, MV Struglia, Sanna A, Torma C, Vervatis V (2015) MED-CORDEX initiative for Mediterranean Climate studies BAMS accepted

Sanchez-Gomez E, Somot S, Josey SA, Dubois C, Elguindi N, Déqué M (2011) Evaluation of Mediterranean Sea water and heat budgets simulated by an ensemble of high resolution regional climate models. Clim Dyn 37:2067-2086. doi:10.1007/ s00382-011-1012-6

Sanna A, Lionello P, Gualdi S (2013) Coupled atmosphere ocean climate model simulations in the Mediterranean region: effect of a high-resolution marine model on cyclones and precipitation. Nat Hazards Earth Syst Sci 13:1567-1577

Sevault F, Somot S, Alias A, Dubois C, Lebeaupin-Brossier C, Nabat P, Adloff F, Déqué M, Decharme B (2014) A fully coupled Mediterranean regional climate system model: design and evaluation 
of the ocean component for the 1980-2012 period. Tellus A 66:23967. doi:10.1007/s00382-015-2507-3

Soto-Navarro J, Criado-Aldeanueva F, García-Lafuente J, SánchezRomán A (2010) Estimation of the Atlantic inflow through the Strait of Gibraltar from climatoloical and insitu data. J Geophys Res. doi:10.1029/2010JC006302

Soto-Navarro J, Somot S, Sevault F, Beuvier J, Criado-Aldeanueva F, Lafuente JG, Béranger K (2015) Evaluation of regional ocean circulation models for the Mediterranean Sea at the Strait of Gibraltar: volume transport and thermohaline properties of the outflow. Clim Dyn 44:1277-1292. doi:10.1007/ s00382-014-2179-4

Tsimplis MN, Baker TF (2000) Sea level drop in the Mediterranean Sea: an indicator of deep water salinity and temperature changes? Geophys Res Lett 27(12):1731-1734
Tsimplis MN, Bryden HL (2000) Estimation of the transports through the strait of Gibraltar. Deep-Sea Res I 47:2219-2242

Uppala SM, Kållberg PW, Simmons AJ, Andrae U, da Costa Bechtold V, Fiorino M, Gibson JK, Haseler J, Hernandez A, Kelly GA, Li X, Onogi K, Saarinen S, Sokka Allan RP, Andersson E, Arpe K, Balmaseda MA, Beljaars ACM, van de Berg L, Bidlot J, Bormann N, Caires S, Chevallier F, Dethof A, Dragosavac M, Fisher M, Fuentes M, Hagemann S, Hólm E, Hoskins BJ, Isaksen L, Janssen PAEM, Jenne R, McNally AP, Mahfouf JF, Morcrette JJ, Rayner NA, Saunders RW, Simon P, Sterl A, Trenberth KE, Untch A, Vasiljevic D, Viterbo P, Woollen J (2005) The ERA-40 re-analysis. Q J R Meteorol Soc 131:2961-3012 